\title{
Architectural Heritage Investigation in Interwar Vilnius: Problems and Methods ${ }^{1}$
}

Edita Povilaitytè-Leliugienè

Vilnius Academy of Arts

Maironio St. 6, LT-01124 Vilnius

Edita.e@gmail.com

This paper presents the architectural heritage research problems and methods in Interwar Vilnius. Due to institutional regulation as well as state law recommendation, architectural heritage research had to be performed before any maintenance (conservation, restoration or adaptation) works, however the quantity and quality of investigations differ from general cognition (general knowledge of an object's constructions, architectural details and condition) and inventory made (survey drawings) and analysis of non-intrusive research methods to complex scientific research. The comparative analysis of institutional impact for the investigation and individual practices of researchers reveal much wider contexts of the architectural heritage investigations questions and methods used in Interwar Vilnius.

Keywords: Architectural heritage research, heritage preservation, intrusive and non-intrusive research, conservation, restoration, inventory, Interwar Vilnius.

1 The paper was prepared for the research 'Art and Architecture of Vilnius in 1919-1939: Institutional Aspect' which is financed by the Research Council of Lithuania based on the National Research Programme 'Modernity in Lithuania' (contract No. S-MOD-17-12). 


\section{Introduction}

Architectural heritage research is one of the most important investigations carried out to understand historical buildings, their structures, complexes or ruins. It is also one of the most important parts of preservation and maintenance works. Architectural heritage research was quite intensive in Interwar Vilnius in spite of the lack of state financial support, although it would be considered insufficient when compared with later research and findings. However, due to documents being lost as well as difficulties in finding the personal archives of the researchers, which now are in different institutions (Lithuania and Poland), or their disappearance, it is quite difficult to reconstruct a general view of architectural research, theories, principles or methods. The search for original documents which would reflect the aspects and findings of architectural heritage research was poor in Poland for several reasons: first, some personal archives are still in private ownership (family), second, some have been lost, third, due to time and limited finance not all institutions were checked, fourth, the number of archival documents on heritage maintenance from Interwar Vilnius heritage was very fragmented in Poland institutions. Moreover, the poor message in papers, articles of that time or later short interpretations of different architectural heritage object investigations in Interwar Vilnius did not represent the real situation. There were more discussions about institutional or law-based research, however, analysis of architectural heritage research was neglected. Therefore, due to this gap this paper will discuss one of the most important segments before heritage preservation and maintenance (conservation, restoration, rehabilitation or reconstructions) works - architectural heritage research. This segment is usually treated as a whole in other papers and not analysed separately. The Nijolè Lukšionytè-Tolvaišienè analysed what themes of art and architecture history studies were investigated in interwar ${ }^{2}$. However, the author of this paper failed to find any studies about architectural heritage research, except for discussions about this subject in general papers about interwar heritage. Furthermore, according to papers published about Interwar Vilnius there were not sufficient discussions about the evaluation of the quantity and quality of architecture heritage research before

2 Nijolė Lukšionytė-Tolvaišienė, „Menotyros mokslas tarpukario Vilniuje“, in: Meno istorija ir kritika (Art History \& Criticism), t. 7: Meno istorijos riboženkliai, Vilnius, 2011, pp. 64-76. 
maintenance works. The first concept for this paper was to analyse architectural research, however the archival sources outlined a wider discussion about architectural heritage research which embraced non-destructive and destructive research methods from historical, archival, art historian, urbanistic to archaeological, architectural, polychromic research ${ }^{3}$.

Therefore, the main aim of this paper is to reveal an account of the intellectuals who emphasised the importance of architectural heritage research, their questions and problems. Research questions will include an understanding of the heritage research processes and problems in Interwar Vilnius. Firstly, it will seek to understand how and how much the architectural heritage objects were researched before preparing the heritage preservation and conservation, restoration or rehabilitation projects as well as before any maintenance works. Secondly, the questions discussed as well as what methods were used for the research and what problems the researcher in Interwar Vilnius had will be analysed. The third research question of this paper will be to understand whether the research was inspired by local institutions and whether the researchers could be related more with the general Polish tendency of heritage research. Thus, this paper will be based on a historical analysis of archival documents and reconstruction of the research methods used in Interwar Vilnius. The geographical location of the paper embraces Interwar Vilnius city which was the main city of the Conservator in Vilnius and Nowogródek Voivodeship, with some examples from Vilnius district due to some important object or due to statistical comparison.

\section{HERITAGE INVESTIGATION: INSTITUTIONAL ASPECT}

Architectural heritage research as an integral and indivisible field in Interwar Vilnius was partially regulated by laws of the Republic of Poland and was also inspired by institutional activities of newly established institutions. As Jūratė Markevičienè noted the preservation of heritage was of interest to society, but was hard to realise without the participation of the state as it regulates the sphere, and also provides financial support ${ }^{4}$. Firstly, heritage research was regulated in two documents for the preservation of art

3 Jonas Rimantas Glemža, Nekilnojamojo kultūros paveldo apsauga ir tvarkymas, Vilnius: Vilniaus dailès akademijos leidykla, 2002, pp. 82-84.

4 Jūratė Markevičienė, „Kultūros paveldo saugos raiška: mokslinės, emocinės ir teisinès prielaidos“, in: Vilniaus kultürinis gyvenimas 1900-1940, Vilnius: Lietuvos literatūros ir tautosakos institutas; 1998, p. 272. 


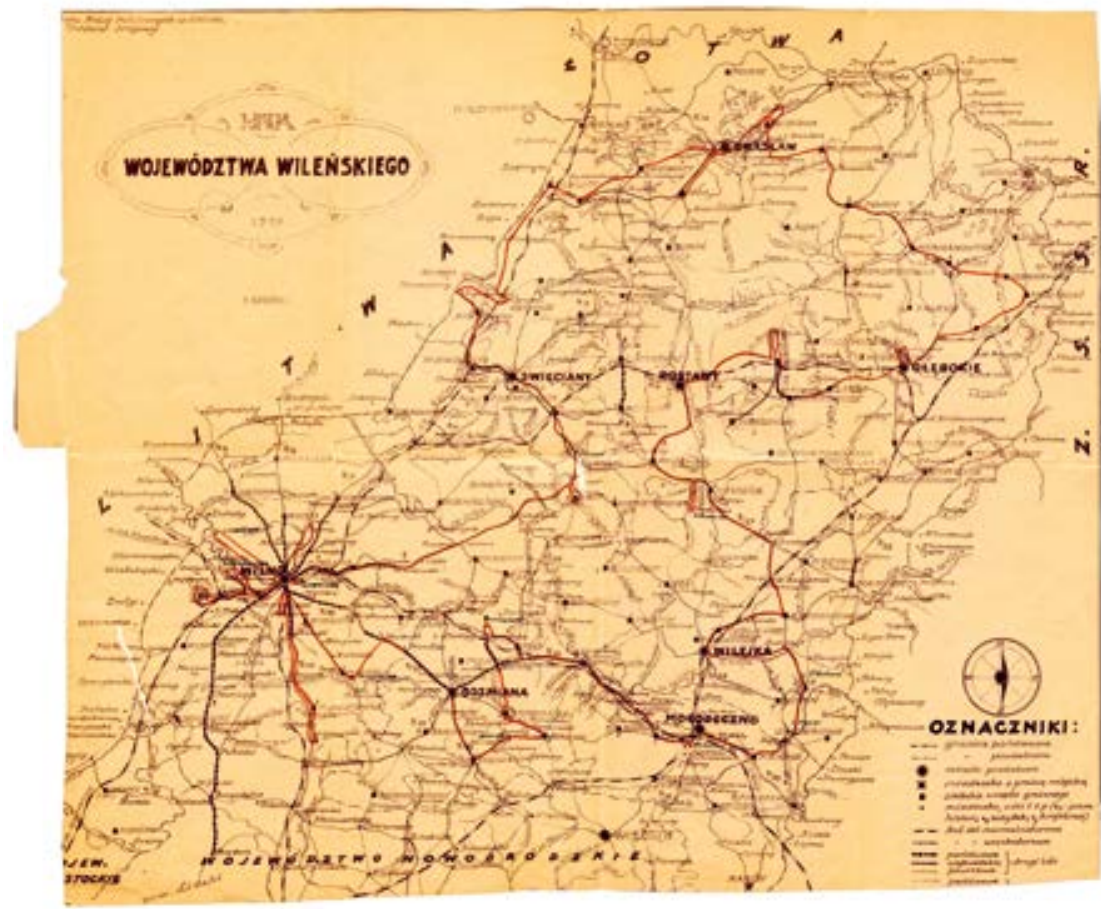

1.

The map of Vilnius Voivodeshipt, 1929, Lietuvos $\quad$ Vilniaus vaivadijos žemèlapis, 1929 mokslų akademijos bibliotekta, RS f. 229_1830

and cultural objects in the Republic of Poland. These two documents were modern at that time due to the theoretical base which suggested complex heritage maintenance as well as the duty to not only preserve the historical substance but also the landscape values and spatial layout of monuments.

The first document, which was created and signed on 31 October 1918, emphasised the need for a heritage inventory and it also noted that the investigation of heritage objects should be carried out by skilled specialists and researchers ${ }^{5}$. The second document, published on 6 March 1928 mentioned that research should be carried out on every heritage object to establish the cultural value ${ }^{6}$. These two documents were supplemented by the "Instruction for the Conservator" which regulated the works

5 Dekret Rady Regencyjnej z 31 października 1918 r. o opiece nad zabytkami sztuki i kultury, 31 października 1918, [online], 1918, [cited 2019-11-15], https://pamiecpolski.archiwa.gov.pl/ dekret-rady-regencyjnej-z-dnia-31-x-1918-r/.

6 Rozporządzenie Prezydenta Rzeczypospolitej z dnia 6 marca 1928 r. o opiece nad zabytkami, [online], 1918, [cited 2019-11-15], http://g.ekspert.infor.pl/p/_dane/akty_pdf/ DZU/1928/29/265.pdf\#zoom=90. 
and responsibilities of the conservators ${ }^{7}$. This instruction noted that in the case of complicated research, experts and specialist institutions should be involved in the research. These documents were criticized, because their had not strong regulation validity due to lack connections with other state law documents. As the inscribe rule mostly every political document could be criticized so the lack of these documents was that the connection with other political law documents was very weak ${ }^{8}$. The heritage preservation and maintenance institutional system model was established last in Vilnius Voivodeship [illus. 1].

Due to the lack of state finances only eleven Conservator offices were established in the sixteen Voivodeships up to World War II $^{9}$. The offices were small; besides the Conservator there were usually only one or two others and this number was hardly sufficient to control already registered objects and to evaluate other objects within their territory ${ }^{10}$. As Karolina Zimna-Kawecka noted: "The effectiveness of conservators largely depended on their social position and prestige, since in this way they could have influenced the decisions made by voivodes and forced through recommendations concerning monuments and statues"11.

Vilnius and its region was officially annexed after Poland's Seym decreed (November 1922) that Polish law was now in force in the territory. This led to the office of Government Delagate (Urzed Rzadu na ziemię Wilenska) being established; it in turn founded an Art Department of

7 Instrukcja Ministra Wyznań Religijnych i Oświecenia Publicznego z dnia 2 czerwea 1930 r. wydana w porozumieniu z Ministrem Spraw Wewnętrznych o prawach i obowiązkach Konserwatorów, jako fachowych organów wojewódzkich władz administracji ogólnej, [online], 1918, [cited 2019-11-15], http://prawo.sejm.gov.pl/isap.nsf/download.xsp/WMP19301560239/O/M19300239.pdf.

8 Paweł Dettloff, Odbudowa i restauracja zabztków architekturz w Polsce w latach 1918 1939: Teoria i praktyka, Kraków: Towarzystwo Autorów i Wydawców Prac Naukowych "Universitas"; 2006, pp. 45-48.

9 The offices of conservation were in Warsaw (two offices), Krakow, Lvov, Poznan, Vilnius, Lublin, Katowice, Kielce, Luck and Torun; Jerzy Remer, “Trzydziestolecie konserwatorstwa polskiego", in: Ochrona Zabytków, R. 1/2, Warszawa, Kraków, 1948, p. 63.

10 As an example, the Conservator of Vilnius office inspected two Voivodeships: Vilnius Voivodeship which included eight districts and an area of 28,900 $\mathrm{km}^{2}$ and Nowogródek Voivodeship which included 12 districts and an area of $22,966 \mathrm{~km}^{2}$.

11 Karolina Zimna-Kawecka, "Ochrona zabytków i organizacja urzędów konserwatorskich w Polsce okresu międzywojennego (na przykładzie woj. pomorskiego) a unormowania Ustawy z dn. 23 VII 2003 r. o ochronie zabytków i opiece nad zabytkami / Monument protection and organisation of conservation offices during the interwar period in Poland (on the example of Pomeranian Voivodeship) and the norms in the Act from 23 July 2003 concerning monument protection and care for monuments", in: Wiadomości Koserwatorskie, No. 27/2010, p. 129. 
which the conservator was appointed head. The conservator was appointed by the Ministry of Religious Beliefs and Public Enlightenment (Ministerstwo Wyznań Religijnych i Oświecenia Publicznego). The first conservator (1922-1928) for Vilnius region was Jerzy Remer (1888-1979) and he assumed office with responsibility for curating heritage preservation to fixed territory from February $1923^{12}$. Other conservators who worked in the Conservator office of Vilnius district (Zarząd konserwatorskie Wojewódstwa Wilenskiego) included Stanisław Lorentz (1928-1936), Franciszek Ksawery Piwocki (1936-1938), Witold Kieszkowski (1938-1939) as Jerzy Remer later appointed to a high post in Poland ${ }^{13}$. It was here that they further crystallised their works and investigations.

Having familiarised himself with Vilnius region and analysed the situation, Remer concluded that this sphere (architectural heritage preservation and investigation) had been neglected due to political changes, the consequences of World War I and the absence of heritage registration and preservation systems ${ }^{14}$. However, as Nijolè Lukšionytė-Tolvaišienè noted about the investigation of heritage "the segment of Poland culture was not implanted into an empty place [...]"15. Even at the beginning of the 20th century it was quite interested in architectural and art heritage, although there were no special institutions to investigate problems in this sphere. Heritage was documented by photographers, artists and architects, and it was also researched, analysed and identified ${ }^{16}$. Moreover, the cultural heritage of the lands of the Lithuanian Grand Dukes was protected at the

12 Jolanta Fedorovič, „Nekilnojamojo kultūros paveldo apsauga Vilniaus krašte 1920-1939 metais: lenkiško paveldosaugos modelio raiška“, in: Lietuvos istorijos studijos, t. 29, Vilnius: Vilniaus universitetas, 2012, p. 89.

13 For example, Jerzy Remer appointed the General Conservator of Heritage (Generalnym konserwatorem zabytków) position (1930-1937), Stanisław Lorentz - director (1936-1982) of Warsaw National Museum (Muzeum Narodowego w Warszawie), Franciszek Ksawery Piwocki - director of Lvov Museum of Artistic Crafts (Muzeum Przemysłu Artystycznego we Lwowie) from 1938 till Second World War, Witold Kieszkowski - general conservator (1945-1949) in the General Directorate of Museums and Monuments Protection (Naczelnej Dyrekcji Muzeów i Ochrony Zabytków).

14 Józef Poklewski, "Organizacje artystyczne i intztucje opieki nad sztuką w międzywojennym Wilnie”, in: Kultura międzywojennego Wilna, Białystok: Towarzystwo Literackie im. Adama Mickiewicza, 1994, p. 178; Jolanta Fedorovič, op. cit., p. 90.

15 Nijolè Lukšionytė-Tolvaišienè, op. cit., p. 66.

16 Photographers Józef Czechowicz, Jan Bułhak consciously documented the heritage objects as well as an example Miron Butkowski or Jan Bułhak fixed the heritage object maintenance process (for instance, Vilnius Upper Castle works in 1905 and 1914); Edita Povilaitytė-Leliugienè, „Fotografija paveldo istorijoje: Vilniaus Aukštutinè pilis“, in: Vaizdu tekstai-tekstu vaizdai. Dailes istorijos studijos, Nr. 7, Vilnius: Lietuvos kultūros tyrimų institutas, 2016, p. 138-142. 
institutional level17.

Some heritage investigation questions and problems were covered by the same personalities before and after World War I (e.g. photographer Jan Bułhak, a doctor who enthusiastically researched Vilnius history and historical buildings, Władysław Zahorski or historian archivist Wacław Gizbert-Studnicki and others). They documented the current architectural heritage condition by visual means as the main method to understand the values of it. The heritage identification and primary stylistic analysis as well as the description were made by authors (e.g. Władysław Zahorski) who published guides about Vilnius ${ }^{18}$. Furthermore, historical archival documents and visual materials were analysed and retrospective and reconstructive methods of primary architectural forms were investigated based on primary (archival or earlier drawings) documents ${ }^{19}$.

\section{ARCHITECTURAL HERITAGE RESEARCH PROGRAMMES}

Therefore the research problem raised in this paper on how and how much the heritage was researched in Vilnius during the interwar period is revealed firstly through the institutional aspect and institutions which induced and stimulated heritage investigations. With the new political power in Vilnius, the activities of Vilnius university were recreated, the Conservator office of Vilnius was established, as were several societies which

17 Vilnius Friends of Science Society (Towarzystwo Przyjaciół Nauk w Wilnie, 1907-1939) assembled Polish intellectuals for the care and investigation of heritage due to the aim of the Society to investigate the nature, ethnography, history, economics and statistics of the land; Hienryka Ilgiewicz, ,Vilniaus mokslo bičiulių draugijos (1907-1939) biblioteka: komplektavimas ir fondų raida“, in: Knygotyra, 2011, Nr. 57, p. 218. For example, members of the society opposed the idea of the Vilnius government to establish a water reservoir on Pilies Hill. Edward Szenfeld, "Dlaczego Góra Zamkowa a nie Stołowa?”, in: Kurier Litewski, 1912, 9 (22) lutego; Jan Obst,. "O Górę Zamkową”, in: Kurier Litewski, 1912, Nr. 44, 7 marca; Nastazija Keršytė, „Lietuvos kultūros vertybių globos institucijos Vilniuje XX amžiaus pradžioje“, in: Vilniaus kultürinis gyvenimas 1900-1940, Vilnius, 1998, p. 72-81.

18 LVIA, f. 1135 (Vilniaus mokslo bičiulių draugijos fondas), ap. 8 (Istoriko Vladislavo Zahorskio (1858-1927) asmeninis aprašas), b. 16 (1896 m. Vadovo po Vilnių rankraštis); Władysław Zahorski, Kaplica św. Kazimierza w Wileńskiej Katedrze, Varšava: G. A. Bernštajn, 1901; Idem, Katedra Wileńska, Wilno: Nakład księgarni Józefa Zawadzkiego, 1904; Idem, Kośćiót św. Anny $w$ Wilnie, Wilno: Druk Józefa Zawadzkiego, 1905; Idem, Kośćiót św. Michała i klasztory panien Bernardynek w Wilnie, Wilno: Księg. Stow. Naucz. Polskiego, 1910; Idem, Przewodnik po Wilnie: opracowany na najnowszych źródet, Wilno: nakład i własność drukarni wydawniczej Józefa Zawadskiego, [1910]; Wacław Gizbert-Studnicki, Wilno: przewodnik ilustrowany po mieście i okolicach z planem miasta i dodatkami, Wilno: Żukowski i Borkowski, 1910.

19 For example, the works of Juozapas Kamarauskas. Edita Povilaitytè, Rima Rutkauskienè, Juozapas Kamarauskas: architekto inžinieriaus kūrybinis palikimas Lietuvos dailès muziejuje, Vilnius: Lietuvos dailès muziejus, 2016. 


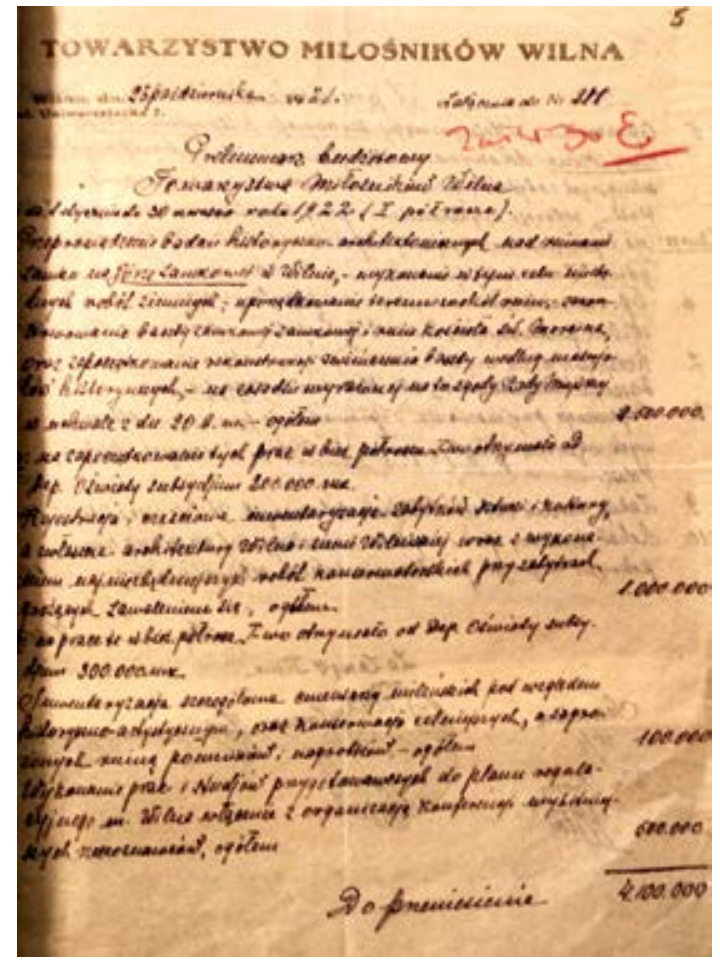

2.

The preliminary budget of the Society of Lovers of Vilnius for 1922, 19211021 , KPC PB, f. 22, ap. 1, s.v. 4, l. 5.

Preliminarus Vilniaus mylètojų draugijos biudžetas 1922 metams, $1921 \mathrm{~m}$. spalio $21 \mathrm{~d}$.

were very active in contributing to heritage preservation, investigation and popularisation works. The Vilnius Friends of Science Society (Towarzystwo Przyjaciót Nauk w Wilnie, 1907-1939) continued their activities and the Society of Lovers of Vilnius (Towarzystwo Milośników Wilna, 1919-1937) were actively involved in heritage investigation and the preservation of Vilnius architectural and historical heritage objects. Therefore, programmes were created for architectural heritage research.

To illustrate the ambitions of architectural heritage research as well as the need of documentation, presentation and other aspects of architectural heritage problems raised by intellectuals we could look to the 1922 budget of the Society of Lovers of Vilnius ${ }^{20}$. According to this document works were planned for non-intrusive field work to intrusive research of Vilnius Upper Castle, documentation and inventory of Vilnius architecture and cemeteries, scientific research of Vilnius architecture and preparation 
for publications about Vilnius etc. The plans were very wide and ambitious, however, these intentions were dampened due to the lack of finances until later [illus. 2]. It needs to be emphasised that there was a lack of finances throughout the interwar period. In some cases, as for example, Vilnius Cathedral, maintenance and research were financed due to the extremely critical situation of the building.

However, the intellectuals' direct and indirect contribution to heritage research was huge. In Interwar Vilnius, Western European heritage research problems, ideas, thoughts, methods were alive and the intellectuals tried to these apply to their works here. For instance, a clear example could be that of Juliusz Kłos, who created the basis of scientific architectural research and the inventory of heritage objects. He organised and implemented surveys and an inventory of heritage objects with the main Vilnius region conservator, Jerzy Remer.

In particular, in the absence of any publication on the architecture or arts in Interwar Vilnius, heritage researches were closely related with heritage maintenance works. According to the many changes and reconstruction works of sacral buildings in the 19th century as well as some that suffered during World War I, special attention was paid to these objects (twenty-one sacral buildings were maintained and seven in Vilnius region) ${ }^{21}$. However, attention was also paid to defensive and representative buildings (eleven civil object and four in Vilnius region) ${ }^{22}$. Research was carried out on more or less every object before any maintenance works. The quantity and quality of the heritage investigation could be seen from the heritage research and maintenance programmes, which were performed before any works on the object and these programmes were prepared by the commissions.

This paper will present three research and maintenance programmes which reveal the changing attitude to architectural heritage research. Moreover, these programmes reveal the deepening realisation of the heritage object as a complex of historical aspects and different science sources. The first programme, which was prescribed for the Church of St. Ignatius, reflects planned minimal research methodologies due to the urgent need for maintenance works and huge reconstruction works in the 
19th century. During the last reconstruction works, this church lost numerous characteristic elements of Vilnius Baroque ${ }^{23}$. So, this programme was made before planned capital maintenance works whose aim was to recreate/ reconstruct the building for worship. The commission was held in December $1922^{24}$. The main conservator, Jerzy Remer, tried to get agreement that the object would be researched before the maintenance works. The report of 23 December 1922 ascertained that the interior had undergone several reconstructions and that many of the décor elements had been destroyed in the 19th century ${ }^{25}$. Thus, as part of the planned capital maintenance works in the very first research programme it was planned: first, to investigate the current layout of the object, second, to do field research of the church and annex masonries and third to prepare the work programme ${ }^{26}$. Juliusz Kłos and Jerzy Remer were charged with carrying out these works. Juliusz Kłos prepared the survey drawings, as well as the non-intrusive investigation of the architectural research of the object, and also prepared the reconstruction projects ${ }^{27}$. In the 18 November 1925 report, Juliusz Kłos emphasised that even though huge reconstruction works had been carried out in the 19 th century, a scientific inventory and documentation of architectural findings should be made during further maintenance works ${ }^{28}$ [illus. 3].

The second research programme for Vilnius Upper Castle was prepared by Vilnius city architect Stefan Narębski. This decision was taken during a meeting of conservators in 1925 due to the bad condition of the castle tower and the need to demolish the additional wooden storey. Moreover, later after some parts of the Castle Palace fell in 1930, another research programme was prepared. It was first planned to carry out an intrusive (non-intrusive) investigation of the north wall of the tower to ascertain the location of the primary landing to the ground floor. The second stage was to investigate the interior of the tower to establish the direction of beams so as to locate the ceiling joists and the third stage involved digging two trenches and some holes in the castle yard and rampart to ascertain the

23 Paminklu squvadas, Vilnius: Vyriausioji enciklopedijų redakcija, 1988, p. 173.

24 KPC PB, f. 22, ap. 1, b, 16, 1. 12.

25 Protokoł, komisji Oględzinewej w sprawie poklacztornego kosciola p.w. Sw. Ignacego w Wilnie, in: KPC PB, f. 22, ap. 1, b, 16, 1. 18-19.

26 KPC PB, f. 22, ap. 1, b, 16, 1. 28.

27 Kościoł Św. Ignacego, in: LVIA, f. 1135, ap. 12, b. 69.

$28 \mathrm{KPC} \mathrm{PB,} \mathrm{f.} \mathrm{22,} \mathrm{ap.} \mathrm{1,} \mathrm{b.} \mathrm{16,} \mathrm{1.} 38$. 


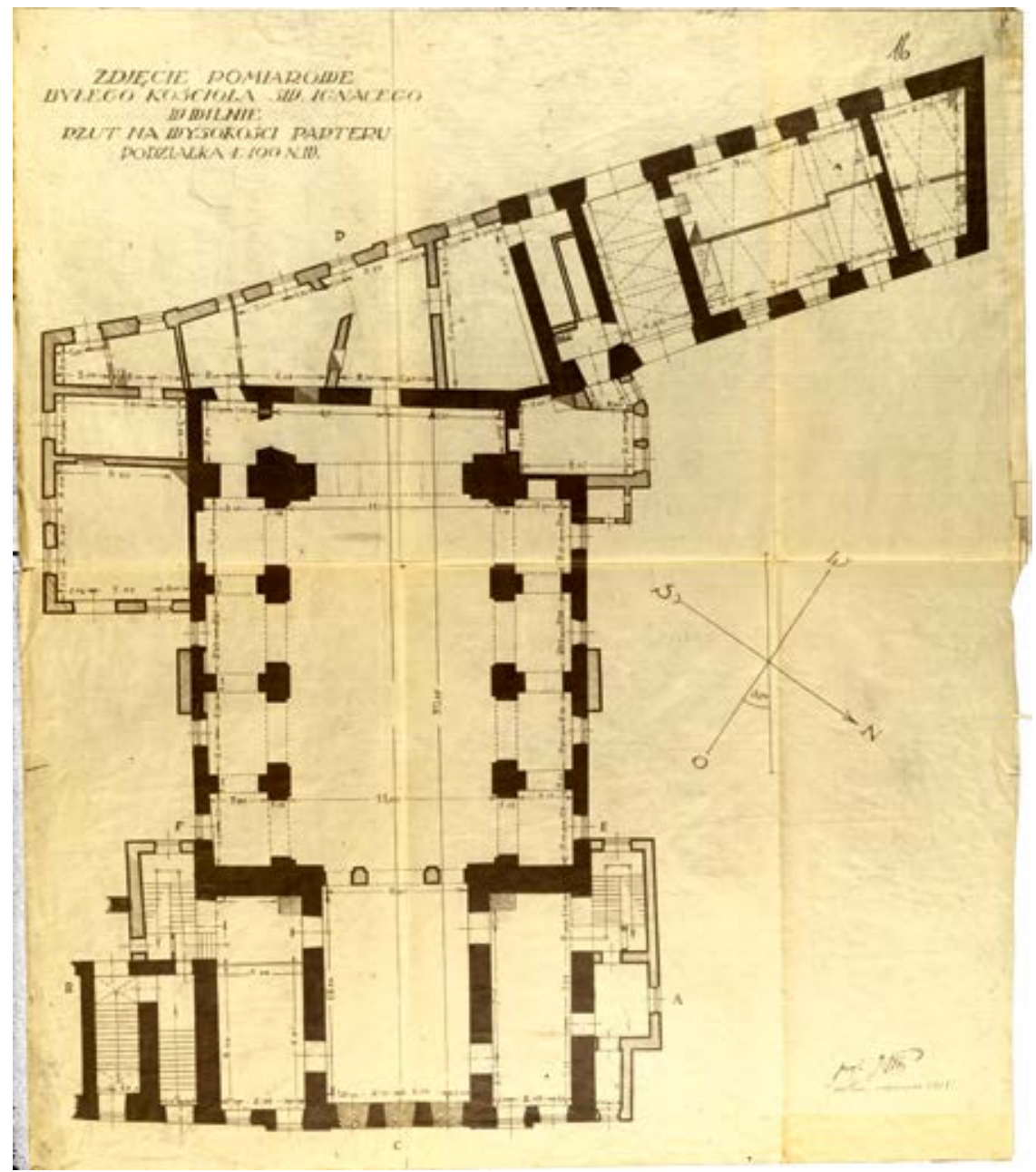

Juliusz Kłos, St. Ignatius Church architectural survey, plan, LVIA, f. 1135, ap. 12, b. 69, l. 16
Juliuszas Kłosas, Šv. Ignoto bažnyčios architektūrinis planas 


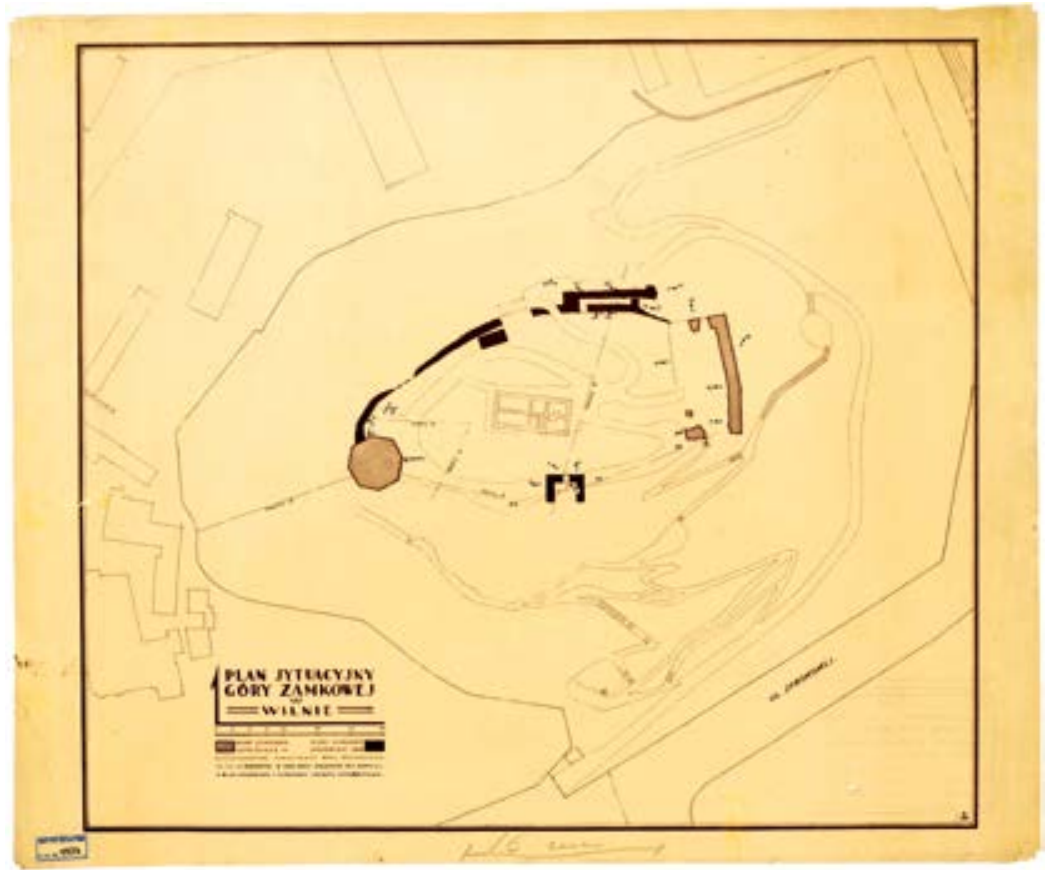

4.

[Józef Rouba] signed R., Plan of the defensive walls of Vilnius Upper Castle after the 1930 architectural intrusive investigation, 1930, ISPAN, No. inv. Rp. 1523
Józefo Roubos (pasirašyta „R.“) Vilniaus Aukštutinès pilies gynybinių sienų planas po $1930 \mathrm{~m}$. įsiterpiančiosios architektūrinès analizès, 1930

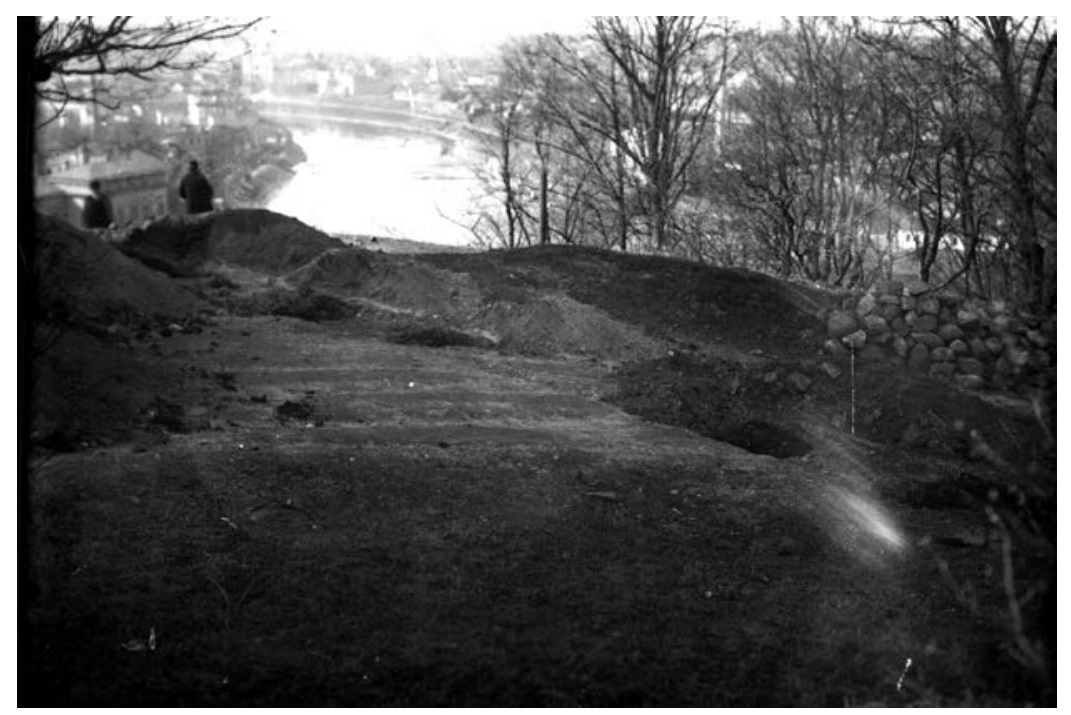

5.

Jan Bułhak (?), View to the second excavation trench in the yard of Pilies hill, 1930, KPC PB, f. 44, ap. 1, neg. 4189
Janas Bułhakas (?), Antroji kasinėjimų tranšèja Pilies kalno kieme, 1930 
primary level of the original castle yard and the castle walls, which would allow further research. This research programme began in 1930. The programme was much wider and embraced not only an architectural survey, layout analysis or field research of the architecture but was much deeper and more complex, due to the incorporation of different types of archaeological and geological research [illus. 4 and 5]. It was also planned to carry out a more intrusive investigation of the brickwork. However, as the research analysis was carried out in parallel with conservation works, the quantity and quality of the research was diminished due to the continuous lack of funds. It should also be noted that the material documenting this research - apart from some solitary sources and drawings which were found in the archives - were not found. The accounts of conservation works on Vilnius Upper Castle were documented (photographs, drawings). The archives contained photos and stratigraphy drawings, but there was very little written analysis of the research performed ${ }^{29}$. So, the reconstruction of this research is based on several sources such as official letters, reports or articles in the newspapers, which does not always reveal the entire view, thus supporting the opinion that information should be analysed like a puzzle.

The third research programme was prepared by architect Juliusz Kłos and conservator Stanisław Lorentz for the Vilnius Cathedral research. The peculiarity of this programme was that the architect constantly changed the tasks of the programme by taking into account new problems and questions that arose during the research processes. The condition of the Cathedral after the flood in 1931 was very bad. Hasty reinforcement works of the building had to be carried out, even though the cathedral had not been scientifically researched before doing so. However, the architect designed a very intensive and complex research programme in order to better analyse the condition of the Cathedral and for the better selection of the technological maintenance works. The research concentrated on the foundations, underground cellar and general soil investigations. The following works were planned as part of the programme: first, to investigate and preserve St Casimir's Chapel, second, to observe the general condition of the Cathedral building, third, to prepare a survey as well as to investigate the 
foundations and the drainage system and finally to analyse the subsoil ${ }^{30}$. The programme was widened to include tasks from technical data collection to scientific data generalisation. According to the communication and works with different specialists such as engineers, it was also planned to recreate the current plan/layout, cross and vertical sections, as well as the building character of the cellars, to count the loads for the foundations, to observe and describe existing and newly found deformations, and to prepare a scientific report of the research results ${ }^{31}$. These complex researches allowed the Cathedral commission to quickly decide and accept the technological solutions to prevent the building from bigger deformations ${ }^{32}$.

Therefore, according to the analysis of these three research programmes it could be argued that heritage objects were investigated from a general perspective and evaluation to a more comprehensive and complex knowledge as well as from the perspective of general heritage monitoring. Based on the Vilnius architectural heritage research programmes it could be preliminarily maintained that there were two distinct stages of architectural heritage research: the first stage was recognition and knowledge which could be linked with the activity of the first conservator Jerzy Remer in Vilnius, and the second stage the complex investigation after 1928.

\section{QUESTIONS, METHODS AND PROBLEMS}

Consequently, the discussed research assignments partially disclose what questions and problems were raised in Interwar Vilnius. Scholars and scientists applied primary survey, field and ground as well as non-intrusive surveys methods. Moreover, they made detailed architectural surveys and inventories. In addition, they tried to collect as much of the available data as possible using field research. However, due to the lack of research documentation, it is sometimes hard to reconstruct the investigation processes during the interwar period, but some intrusive investigations were carried out as well. For instance, original wall-paintings and frescos were uncovered, and examinations carried out, for example, in St. Casimir's Church, the Bernardinai Cloister and the Library of Stephen Báthory University ${ }^{33}$. Likewise, the building materials such as bricks, 
limes, stones and the technical as well as chemical attributions were identified and investigated (such research was also performed partially in Vilnius Upper Castle and the Trakai Island Castles) $)^{34}$. As Jan Borowski noted, the analysis of bricks, limes, stones as well as building process itself is very important: "this research would be valuable for theoretical reasons while wider investigation works will examine the technology of medieval buildings materials and building in general as well as for further research [...]"35.

Comparative stylistic analysis methods were used to analyse the investigations of individual scholars and scientists. Therefore, attention to visual as well as to the archival historical documents was analytical and critical. The analysis of these documents was compared with the field data and current condition of the heritage object. Furthermore, the historical documents, particularly the maps and plans were the basis for the reconstruction of the evolution of the architectural object. An illustration of this could be the research on the evolution of Vilnius University buildings by Juliusz Kłos [illus. 6$]^{36}$. It was equally important, to ascertain the physical properties of buildings and building materials in order to locate original and current non-existing structures.

Particularly important attention was paid to cartography and to the analysis of Vilnius City plans in the 1930s. Firstly, this interest was closely connected with previously unknown and newly discovered plans of Vilnius in the archives. For instance, the 18th century Vilnius City plan made by Johann Georg Maximilian von Fürstenhoff was found in the Berlin National Library Cartography department by W. G. Studnickio in 1939-194037. These new documents thus became important impulses for changing the reconstructive research methods of urban development and building perimeters.

33 Special commissions were organised and specialists from other Polish cities were invited to evaluate and to perform field research about newly discovered and uncovered interior details. For example, based on archival documents, conservator Jerzy Remer invited one of the best known at that time painting conservators, Jan Rutkowski from Warsaw to evaluate and to carry out field research on St. Casimir's Church, Bernardinai Cloister and the Library of Stephen Bátory University where he uncovered frescos on 25 of November 1925; Juozapas Blažiūnas, „Profesorius Janas Rutkowskis. Tarp Ars ir Sacrum“, in: Acta Academiae Artium Vilnensis, Vilnius, 2015, t. 77-78: Dailès ir architektūros paveldas: tyrimai, išsaugojimo problemos ir lūkesčiai, sud. Dalia Klajumienè, p. 187.

34 Jan Borowski, „Trakų salos pilis, kaip tvirtovè ir Didžiojo Kunigaikščio rezidencija, atliktų konservacinių darbų šviesoje“, in: Vytauto Didžiojo kultūros muziejaus metraštis, Nr. 1, sud. P. Karazija, Kaunas: Vytauto Didžiojo kultūros muziejaus leidinys, 1941, Nr. 14, pp. 199-242.

35 Ibid., p. 234.

36 LVIA, f. 1135, ap. 12, b. 17.

37 The photograph copy from the interwar period is now preserved in the Lithuanian National Museum. Vilnius City plan by J. G. M. von Fürstenhoff, 1740, photographic copy, in: LNM, AFP-4261. 

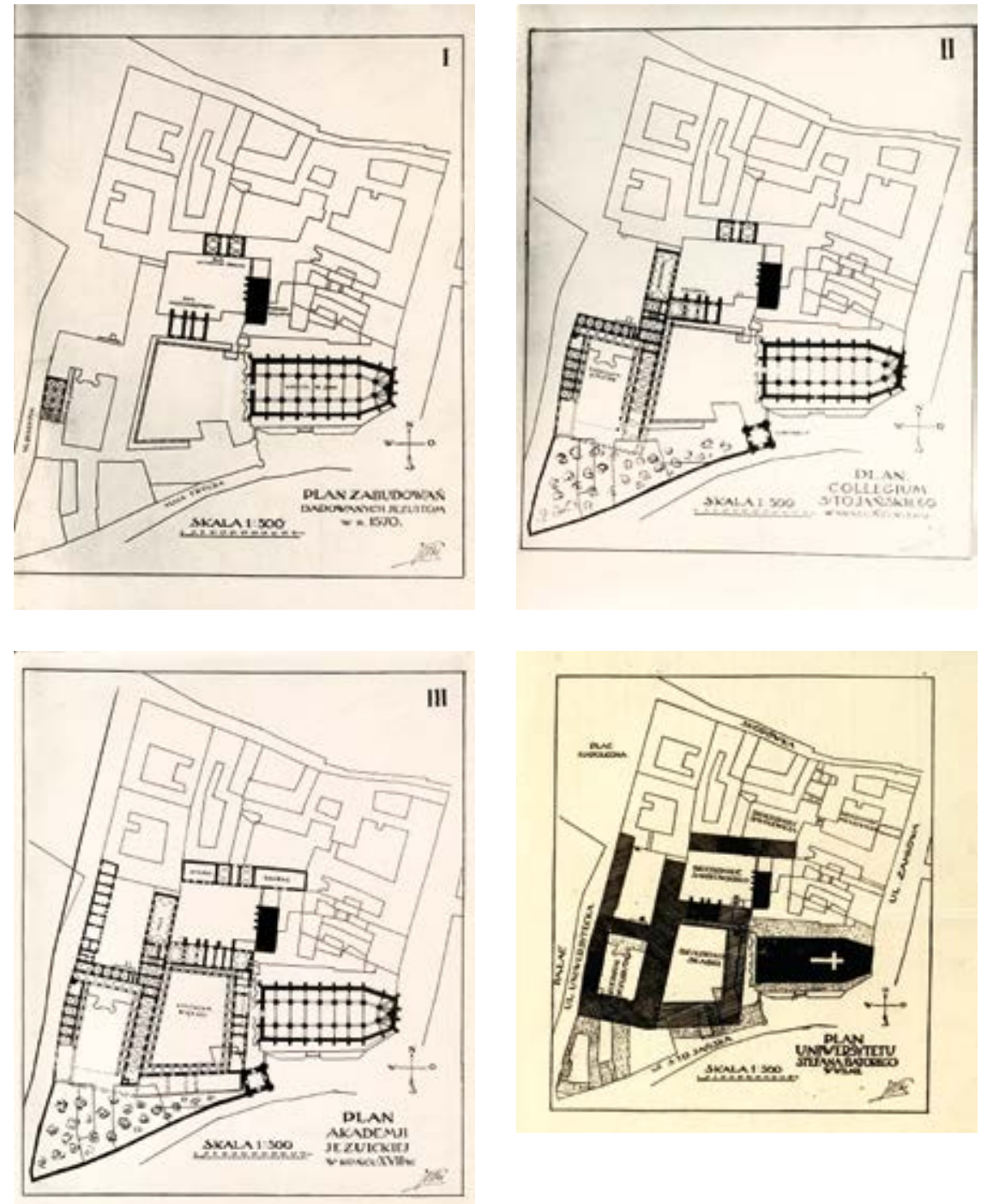

6.

Juliusz Kłos, Reconstruction plans of Vilnius

University complex in 1570,16 th, 17 th, 18 th centuries, LVIA, f. 1135, ap. 12, b. 17, 1. 15, 13, 12, 5

Juliuszas Kłosas, Vilniaus universiteto komplekso rekonstrukcijos planai: 1570 m., XVI a., XVII a. ir XVIII a. 
It could be concluded from the surveys, that field research and inventory making as well as the accumulation of different data about the architectural heritage objects and finds of the oldest buildings and structures in the 1920 s were performed on a much larger scale and were more complex in the 1930s. Mostly these researches where initiated by individual researchers. For instance, Stanisław Lorentz investigated castles ${ }^{38}$, the principal architect of Vilnius City, Stefan Narębski, carried out an analysis of Vilnius City urban development ${ }^{39}$; valuable reconstructions of ancient building structures were made by Marian Morelowski ${ }^{40}$ and later old masonries were analysed by Zygmunt Meczysław Czaykowski ${ }^{41}$.

In spite of primary information, it could be argued, that the biggest problems facing researchers were the patchy historical sources as well as the lack of architectural reconstruction, adaptation for new functions or alteration documents, especially from the 19th century. As a result, their arguments were not considered strong ${ }^{42}$. Moreover, there was also the problem of urgent remediation works, and it is also very likely that detailed documentation and reports about the research or drawings were poorly or not prepared at all due to the lack of funds or weak institutional regulation. However, in some cases there were examples of properly documented research and conservation works for that period. For example, the icon Our Lady of the Gate of Dawn research written by Jerzy Remer ${ }^{43}$ and the other Trakai Island castle by Jan Borowski ${ }^{44}$.

38 Stanisław Lorentz, "Konserwacja ruin zamków w Wileńszczyźnie i Nowogródczyźnie”, in: Ochrona Zabytków Sztuki, 1930/31, Cz 1, z. 1-4; pp. 161-179.

39 Stefan Narębski, "Zarys urbanistycznego rozwoju Wilna i plan zabudowania jego z r. 1817”, in: Prace i Materiały Sprawozdawcze Sekcji Historii Sztuki Towarzystwa Przyjaciót Nauk w Wilnie, Wilno, 1935, t. 2, pp. 339-344.

40 Marian Morelowski, Urbanistyka Wilna XIV i XV, Wilno, in: Zakład Narodowy im. Ossolińskich, Dział Rękopisów (toliau - ZNODR), 14841/II; Idem, Vilnius prieš 1655 metus. Rekonstrukcinio plano 318 numerių paaiškinimas, [Vilnius], [s.a.], in: Vilniaus regioninis valstybès archyvas (toliau - VRVA), f. 1019, ap. 11, b. 4358; Jūratė Markevičienė, „Pamiršta hipotezė, arba Vilniaus miesto sandara XIV-XV amžiuje“, in: Menotyra, sud. Gražina Marija Martinaitienè, Vilnius: Lietuvos mokslų akademijos leidykla, 2002, Nr. 3 (28), pp. 30-45.

41 Documents of architect Zygmunt Meczysław Czaykowski are now preserved in his personal fund in the Cultural Heritage center, Library archive of Heritage in Vilnius. Zygmuntas Meczysławas Czaykowskis, KPC PB, f. 35, ap. 1.

42 Povilas Reklaitis, „Morelowski Marian“, in: Lietuviu enciklopedija, 1959, t. 19, p. 269.

43 Jerzy Remer, Madonna warowni wileńskiej (rzecz o obrazie Matki Boskiej

Ostrobramskiej), Kraków: Drukarnia Narodowa, 1927; Juozapas Blažiūnas, op. cit., p. 197.

44 Jan Borowski, op. cit., pp. 199-242. 


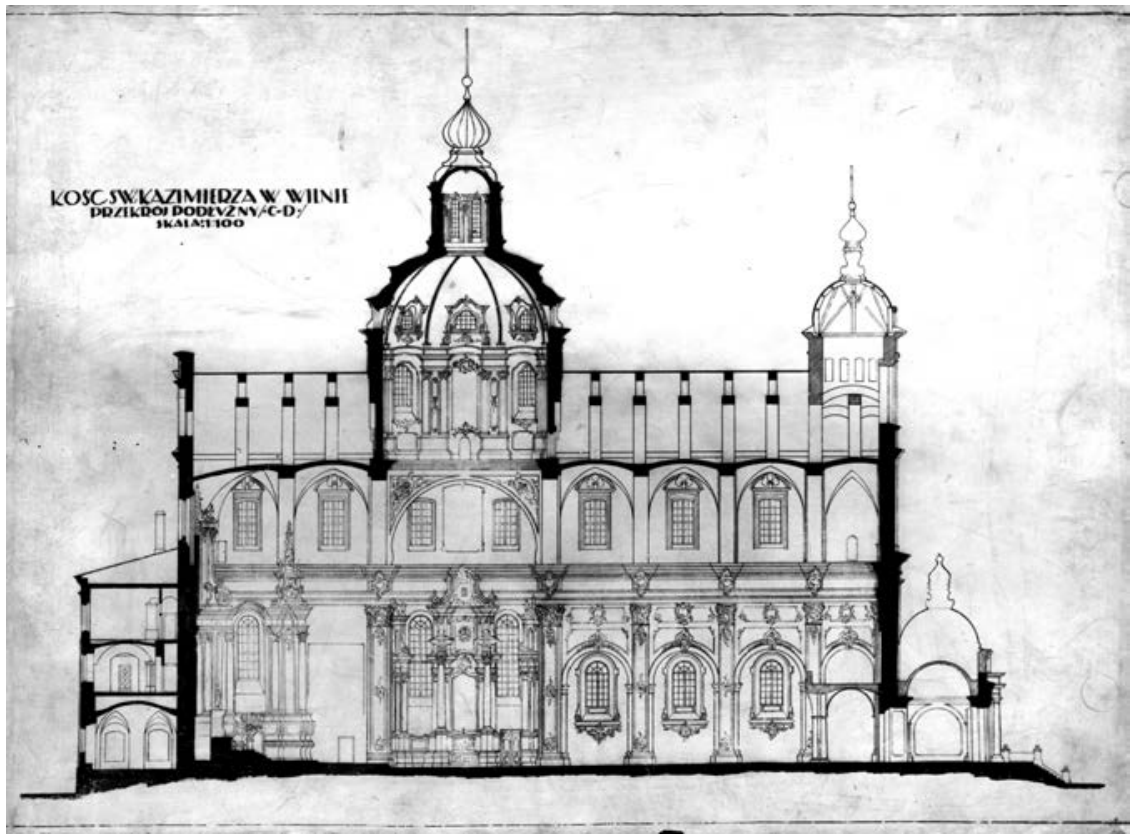

7.

Józef Zdanowicz, Jerzy Sliwka, St. Casimir's Church survey drawing, 1925, KPC PB, f. 6, ap. 1, s.v. 2578.
Józefas Zdanowiczius, Jerzy Sliwka, Šv. Kazimiero bažnyčios apžvalginė schema, 1925

\section{Problems with inventory: survey}

Due to the lack of a heritage inventory system, when the Conservator's office began its work information about the ancient buildings and valuable heritage objects was kept in this office and this information came from different districts ${ }^{45}$. So, the information was unequal. However due to the decree published in 1918 the necessity to have a heritage objects' inventory was emphasised. It is difficult to talk about a technically clear and orderly inventory from the interwar period as the archive of the Conservator's office did not survive entire. However, there were heritage impulse of heritage inventory. However, the heritage inventory documents started to be compile.

Juliusz Kłos was the first to attempt to carry out a heritage inventory in Vilnius and Vilnius region in the interwar period. As Jerzy Szablowski said: "The most important requirement for the conservator is to 


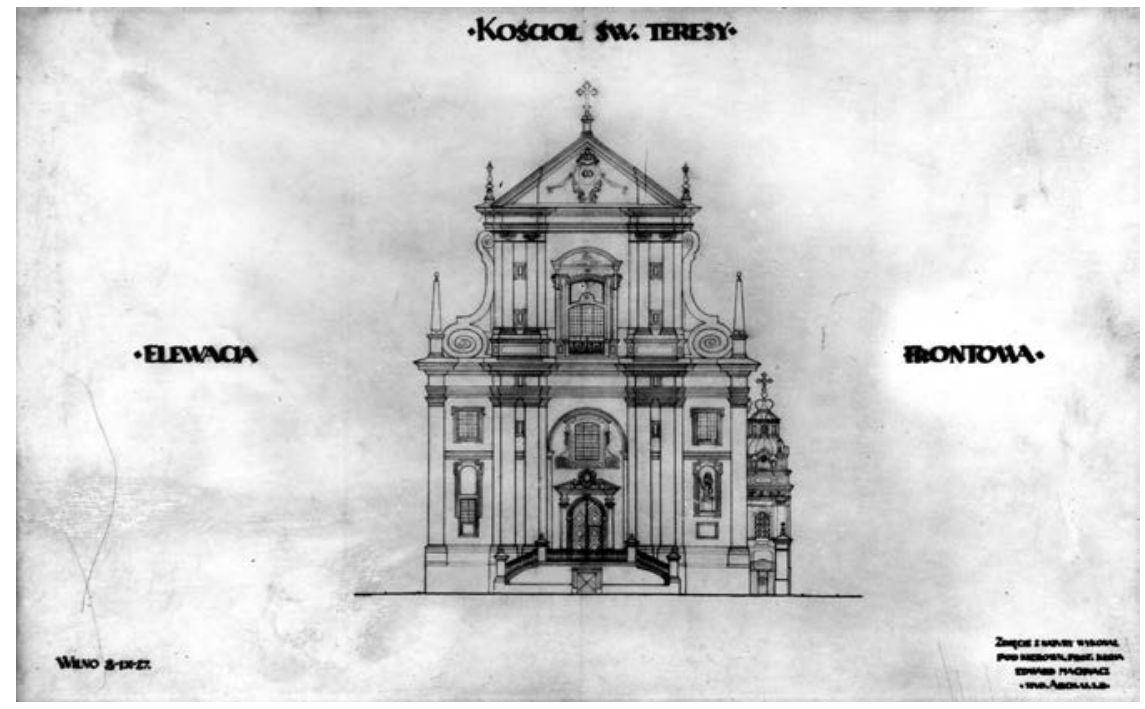

8.

Edward Mahnacz, St Terese Church survey drawing, 1927, KPC PB, f. 6, ap. 1, s.v. 2569

Edwardas Mahnaczas, Šv. Terezės bažnyčios apžvalginè schema, 1927

prepare a complete inventory which should consist of scientific reports, photographs, and measurement drawings of architectural objects [...]"46. Juliusz Kłos brought the ideas for an architectural heritage inventory and documentation from his studies in Vienna and practice which he acquired during his work in the society of past heritage preservation (Towarzystwie Opieki nad Zabytkami Prieszłości, 1912-1914) in Krakow where he was not only secretary to the conservator, but also made an inventory survey of churches and estates in the region ${ }^{47}$. He later developed an interest in photography when he was one of the organisers of the archive of Polish heritage photography and survey in Warsaw Polytechnical University ${ }^{48}$. Consequently, he became keen to photograph and survey architectural heritage an activity which he continued when he came to Vilnius and started to work in Stephen Báthory University.

Juliusz Kłos was also very active in the Society of Lovers of Vilnius

46 Jerzy Szablowski, "Dzieje inwentaryzacji zabytków sztuki w Polsce w dwudziestą rocznicę centralnego biura inwentoryzacji zabytków sztuki”, in: Ochrona Zabytków, No. 2 (6), Czerwiec 1949.

47 Józef Poklewski, "Prof. Juliusz Kłos (1881-1933) architect - badacz - konserwator pedagog - człowiek”, in: Architektura et historia, Torun: Zakład Poligraficzno-Wydawniczy POZKAL, 1999, p. 286.

48 Józef Poklewski, “Prof. Juliusz Kłos (1881-1933)”, p. 284-285. 


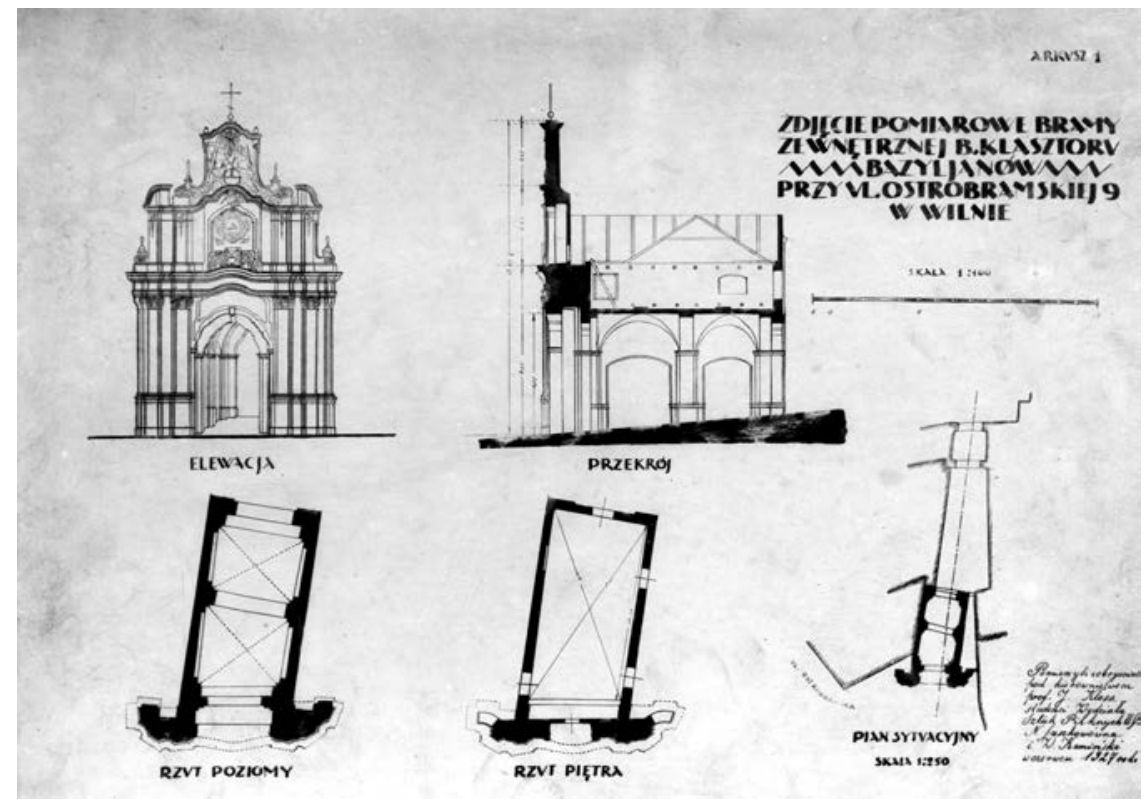

9.

N. Suskowówna, W. Kamiński, Basilian Monastery Gate survey drawing, 1927, KPC PB, f. 6, ap. 1, s.v. 2656.
N. Suskowówna, W. Kamińskis, Bazilijonų vienuolyno vartų apžvalginė schema, 1927

(Towarzystwo Milośników Wilna $)^{49}$. He organised a committee of heritage inventory from $1920^{50}$. The 1922 budget of the Society of Lovers of Vilnius allocated funds to make an inventory of Vilnius and its region heritage objects (5,000,000 zloty) and an inventory and maintenance of gravestones $(100,000 \text { zloty })^{51}$. Juliusz Kłos together with conservator Jerzy Remer arranged for architecture students to take measurements of heritage objects in Vilnius and Vilnius region. According to archival documents of that period the architecture inventory, which was photographed by Jan Bułhak and pasted onto cardboard, showed that all the facades of objects as well as cross-sections were measured ${ }^{52}$. So, the measurements were made by

49 The main aim of the society was to protect Vilnius architectural and historical heritage as well as to take care of the reconstruction of architectural heritage objects. Moreover, the society collected historical material about the old buildings and monuments and other objects; Vilniaus mylètojų draugija [Towarzystwo Milośników Wilna], in: LCVA, f. 1041, ap. 1, b. 1.

50 Józef Poklewski noted that the architectural heritage inventory of Vilnius and its region organised by Juliusz Kłos was anti-Polish, because the Eastern Orthodox church was also inventoried; Józef Poklewski, “Prof. Juliusz Kłos (1881-1933)”, p. 286.

51 Towarzystwo Milośników Wilna 21 października 1921 r., in: Susirašinėjimo dokumentai dèl Vilniaus Bazilijonų vienuolyno „Konrado celès“ ir Vilniaus miesto mylètojų sajungos 1922 metų biudžeto projektas, 1921-1923, in: KPC PB, f. 22, ap. 1, s.v. 4, pp. $2-5$. 
students under the supervision of Professor Juliusz Kłos. For example, we have the survey of Vilnius Cathedral bell tower ${ }^{53}$ and floor plans of the university ensemble (1921) ${ }^{54}$ made by Józef Zdanowicz, an architecture student of the Stephen Báthory Art department; he also made measurements and prepared drawings of St. Casimir's Church in $1925^{55}$ with another student Jerzy Sliwka; student Edward Machnacz made measurements of St. Therese Church ${ }^{56}$ and students N. Suszkowówna and W. Kamiński performer a survey of the Basilian Monastery Gate ${ }^{57}$ both in 1927 [illus. 7, 8, 9]. In Addition, Professor Kłos together with the conservator organised practical work for the students in the region where they measured important architectural heritage objects ${ }^{58}$.

Undoubtedly, survey drawings were also made by specialists. For instance, Juliusz Kłos made detailed drawings of the university Alumno Palace Building in $1928^{59}$, St. Ignot Church ${ }^{60}$, Jan Borowski survey drawings of the Gate of Dawn (1932) $)^{61}$, the bell tower of St. Johns Church ${ }^{62}$. Later,

52 These survey photographs are now in the archive of the Cultural Heritage Center (KPC PB, f. 6, ap. 1).

53 Józef Zdanowicz pod kierunkiem prof. Juliusz Kłos, Dzwonnica przy kościele katedralnym św. Stanislawa w Wilnie, [rzut], w skali 1:100, 1927 (?), in: KPC PB, f. 6, ap. 1, s.v. 2563; Józef Zdanowicz pod kierunkiem prof. Juliusz Kłos, Dzwonnica przy kościele katedralnym św. Stanislawa w Wilnie, [widok I przekroj pionowy], w skali 1:100, 1927, in: KPC PB, f. 6, ap. 1, s.v. 2564.

54 Józef Zdanowicz, in: KPC PB, f. 6, ap. 1, s.v. 477; KPC PB, f. 6, ap. 1, s.v. 478; KPC PB, f. 6 , ap. 1 , s.v. 479 .

55 Józef Zdanowicz, Jerzy Sliwka pod kierunkiem prof. Juliusz Kłos, Kość. Sw. Kazimierza w Wilnie Przekrój poziomy pod chórem, skala 1:100, 1925, in: KPC PB, f. 6, ap. 1, s.v. 2571; Idem, Kość. Sw. Kazimierza w Wilnie przekroj podłyżny /C-D/, skala 1:100, 1925, in: KPC PB, f. 6, ap. 1, s.v. 2578; Idem, Kość. Sw. Kazimierza w Wilnie przekroj podrzeczny, skala 1:100, 1925, in: KPC PB, f. 6, ap. 1, s.v. 2577; Idem, Kość. Sw. Kazimierza w Wilnie elewacja boczna, skala 1:100, 1925, in: KPC PB, f. 6 , ap. 1, s.v. 2576; Idem, Kość. Sw. Kazimierza w Wilnie elewacja tylna, skala 1:100, 1925, in: KPC PB, f. 6, ap. 1, s.v. 2575; Idem, Kość. Sw. Kazimierza w Wilnie elewacja frontowa, skala 1:100, 1925, in: KPC PB, f. 6, ap. 1, s.v. 2574; Idem, Kość. Sw. Kazimierza w Wilnie przekrój poziomz przez pod bsze i kopułę, skala 1:100, 1925, in: KPC PB, f. 6, ap. 1, s.v. 2573; Idem, Kość. Sw. Kazimierza w Wilnie Przekrój poziomy nad chórem, skala 1:100, 1925, in: KPC PB, f. 6, ap. 1, s.v. 2572.

56 Edward Machnacz pod kierunkiem prof. Juliusz Kłos, Koscioł Sw. Teresy elewacja boczna, skala 1:100, 1927, in: KPC PB, f. 6, ap. 1, s.v. 2570; Idem, Koscioł Sw. Teresy elewacja frontowa, skala 1:100, 1927, in: KPC PB, f. 6, ap. 1, s.v. 2569.

57 N. Suszkowówna and W. Kamiński pod kierownistwem prof. Juliusz Kłos, Zjęcie pomiatowe bramy zewnętrznej B. Klasztory Bazyljanów przy ul. Ostrobramskiej $9 \mathrm{w}$ Wilnie, skala 1:100, 1927, in: KPC PB, f. 6, ap. 1, s.v. 2565; Idem, elewacja, skala 1:100, 1927, in: KPC PB, f. 6, ap. 1, s.v. 2566 .

58 Eduardas Budreika, „Mokslinio restauravimo pradininkas“, in: Vakarinès naujienos, 19880130 , p. 3 .

59 Juliusz Kłos, in: KPC PB, f. 6, ap. 1, s.v. 744; KPC PB, f. 6, ap. 1, s.v. 745; KPC PB, f. 6 , ap. 1 , s.v. 746 ; KPC PB, f. 6 , ap. 1, s.v. 748.

60 Juliusz Kłos, Zdięcie pomiarowe byłego kościoła Sw. Ignackiego w Wilnie, rzut na wysakości parteru podiałka 1:100 N.W., 1925, in: LVIA, f. 1135, ap. 12, b. 69, 1. 16. 


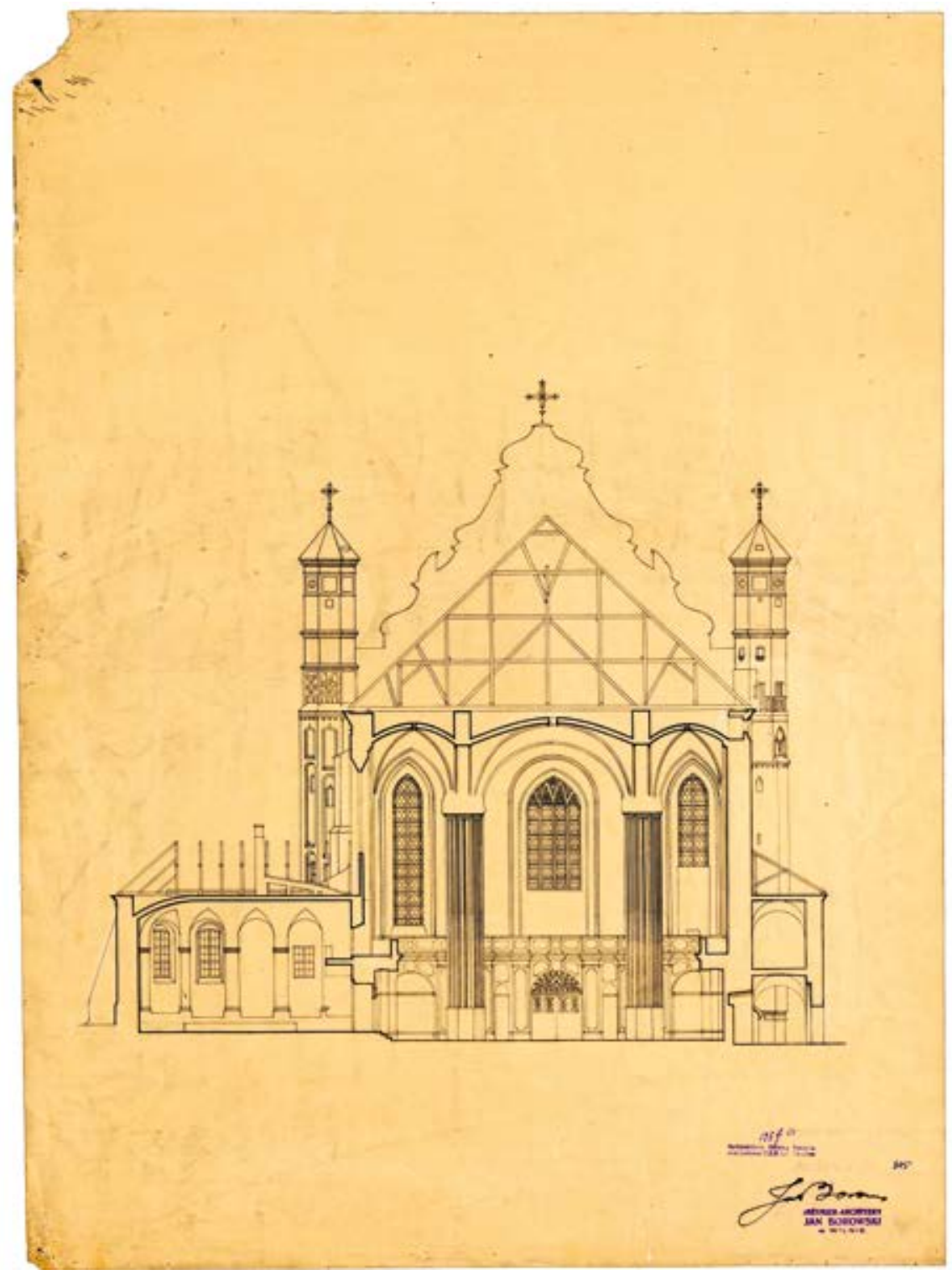

10.

Jan Borowski, [Kazimier Macur], Bernardine Church survey drawing, KPC PB, f. 6, ap. 1, s.v. 305
Janas Borowskis, [Kazimieras Macuras], Bernardinu bažnyčios apžvalginè schema 
with his student Kazimier Macur, he made measurements of the Bernardine Church $^{63}$, Stanislaw Bukowski worked in Vilnius Cathedral ${ }^{64}$ [illus. 10]. Moreover, according to archival sources Jan Borowski worked in Vilnius region and documented the Bernardine ${ }^{65}$ and St. Maria ${ }^{66}$ Churches in Budslaw (now Belarus) in 1926-1927. Piotr Bohdziewicz, Jan Obminska and others also worked in the Vilnius region ${ }^{67}$. They made measurements of sacral buildings, however, there was also some documentation of other buildings in Vilnius.

After 1939, measurement drawings were made as well. Jan Borowski $^{68}$, Piotr Bogdziewicz ${ }^{69}$, and former student of SBU, Józef Zdanowicz ${ }^{70}$ all worked in this area [illus. 11]. With time, other architects and painters got used to or were included in these works. Some drawings were made by Vladas Drèma ${ }^{71}$, N. Suškovaitė ${ }^{72}$, B. Sviecimski ${ }^{73}$, J. Wźesnewski ${ }^{74}$. An amazing numbers of drawings and sketches by Zygmunt Meczyslaw Czaykowski

61 Jan Borowski, KPC PB, f. 6, ap. 1, s.v. 404; KPC PB, f. 6, ap. 1, s.v. 405; KPC PB, f. 6 , ap. 1, s.v. 406; KPC PB, f. 6, ap. 1, s.v. 407; KPC PB, f. 6, ap. 1, s.v. 408; KPC PB, f. 6, ap. 1, s.v. 409.

62 Jan Borowski, KPC PB, f. 6, ap. 1, s.v. 797; KPC PB, f. 6, ap. 1, s.v. 798.

63 Jan Borowski, [Kazimier Macur], in: KPC PB, f. 6, ap. 1, s.v. 302; KPC PB, f. 6, ap. 1, s.v. 303; KPC PB, f. 6, ap. 1, s.v. 304; KPC PB, f. 6, ap. 1, s.v. 305.

64 Stanislaw Bukowski carried out a survey of St. Casimir's Chapel in 1932 (KPC PB, f. 6, ap. 1, s.v. 6751-6752, 6754).

65 Jan Borowski, in: KPC PB, f. 6, ap. 1, s.v. 5494.

66 Jan Borowski, in: KPC PB, f. 6, ap. 1, s.v. 2586-2593; KPC PB, f. 6, ap. 1, s.v. 4000-4006.

67 Piotr Bohdziewicz made measurements of the Basilian Church in Berezvečia (now Belarus, 1929, KPC PB, f. 6, ap. 1, s.v. 1692-1694; 6588), with W. Proszynski did Karmelitu monastery plan in Glemboka (now Belarus, 1928, KPC PB, f. 6, ap. 1, s.v. 5493). Jan Obminska worked with Easter Church chapel in Gaiceniškiai (now Belarus, 1924, KPC PB, f. 6, ap. 1, s.v. 2596-2602), Iškolds Church (now Belarus, 1924, KPC PB, f. 6, ap. 1, s.v. 2579-2585). In addition, a substantial number of the architect's archival documents are now preserved in Warsaw in ISPAN.

68 St. Peter and St. Paul interior drawings (1944-1945; KPC PB, f. 6, ap. 1, s.v. 4452; 4581; 12843-12850; 3307-3310; 48-49; 13880).

69 Piotr Bohdziewicz measured and the copy was prepared by J. Mazurkevičius of St. Casimir's Church (1942, KPC PB, f. 6, ap. 1, s.v. 335-342), Missionary Church (1946, KPC PB, f. 6, ap. 1, s.v. 218-224), St. Ana Church (1946, copy by Vorobjov, KPC PB, f. 6, ap. 1, s.v. 170 - 180), St. Raphael (1941, KPC PB, f. 6, ap. 1, s.v. 205-2011; 344-350), St. Teresa (1946, copy by Vasiliauskaitè, KPC PB, f. 6, ap. 1, s.v.181-201), St. Church of Jesus the Redeemer (1946, copy by K. Baranauskas, KPC PB, f. 6, ap. 1, s.v. 225-230).

70 St. Peter and St. Paul (KPC PB, f. 6, ap. 1, s.v. 41; 46-47; 13879); Eastern church of St. Nicholas (1946, KPC PB, f. 6, ap. 1, s.v. 78-80).

71 He made watercolour facade drawings of the Basilian Masonry Gate (KPC PB, f. 6, ap. 1, s.v. 3311), Bernardine Church (1943, KPC PB, f. 6, ap. 1, s.v. 4582, 12842), Missionary (1943, KPC PB, f. 6, ap. 1, s.v. 3312), St. Ana (1943, KPC PB, f. 6, ap. 1, s.v. 4583).

72 She did drawings of the Basilian Masonry Gate (KPC PB, f. 6, ap. 1, s.v. 351-352).

73 St. Peter and St. Paul (1944, KPC PB, f. 6, ap. 1, s.v. 37-39; 44-45).

74 St. Stephen Church (1946, KPC PB, f. 6, ap. 1, s.v. 98-107). 


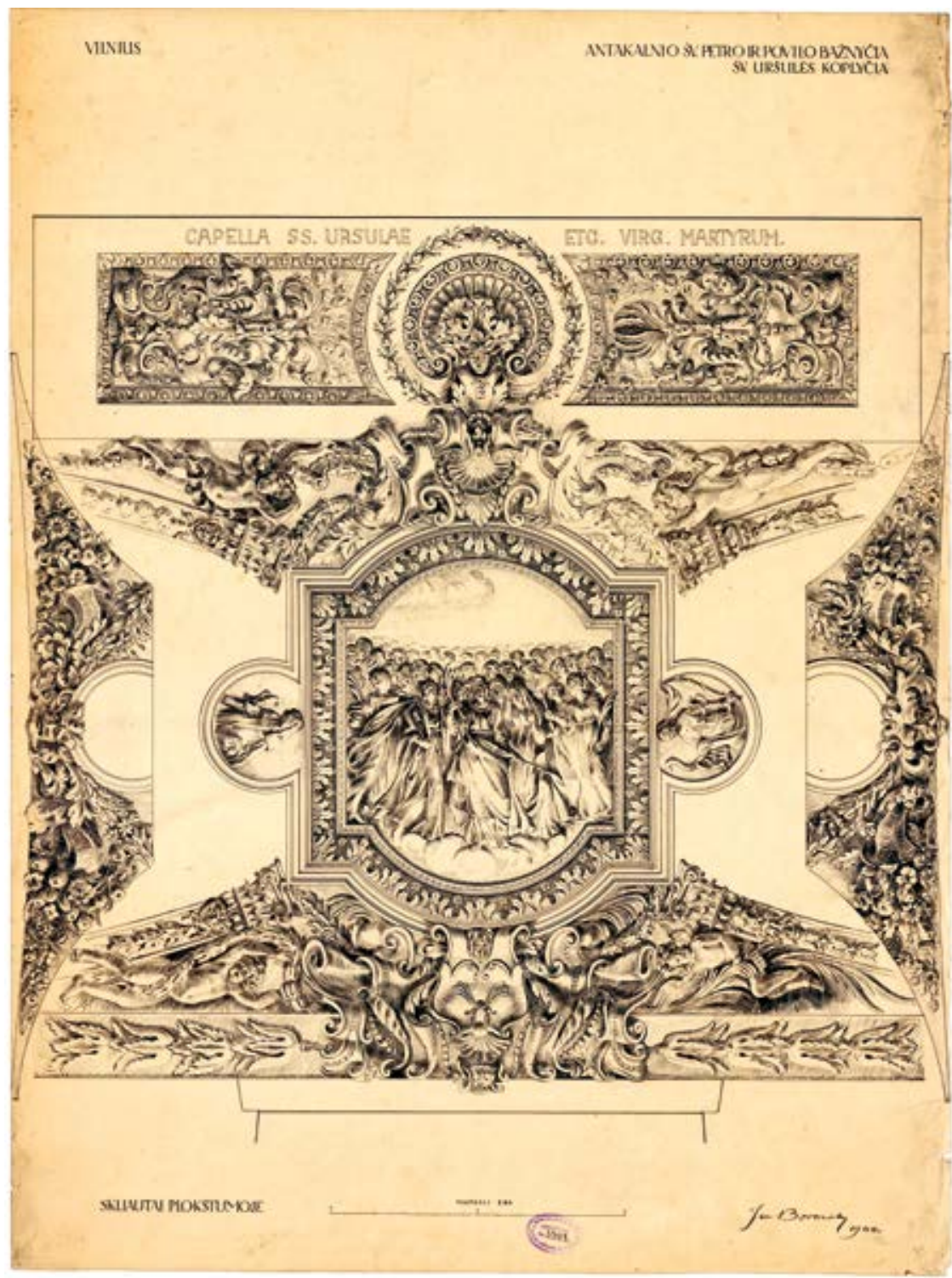

11.

Jan Borowski, St. Peter and Paul church interior survey drawing, 1944, KPC PB, f. 6, ap. 1, s.v. 3308.

Janas Borowskis, Šv. Petro ir Povilo bažnyčios interjero apžvalginè schema, 1944

Edita Povilaitytè-Leliugienè

Architectural Heritage Investigation in Interwar Vilnius: Problems and Methods 
have survived ${ }^{75}$. Some works were closely related with the political situation and World War II.

\section{Documentation of building materials}

Indeed, even if there is a lack of archival documentation of the interwar research history, some examples nevertheless reveal the principals and methods of how scientists worked and documented their investigation. According to a few archival sources, which will be discussed in more detail, buildings materials were registered and inventoried, their physical forms and technical characteristic were investigated; it should also be noted that primary methods of stratigraphy were used. First, the list of findings during the 1933-1937 ground works in the territory of Vilnius Upper Castle revealed different types of profile bricks; other findings included tiles, glazed tiles, ceramics, stone shells and bullets, metal and stone axes, bones etc.

Altogether seventy-six different objects were registered here in quantities from one to two hundred. According to this list there were twenty-two types of profile bricks [illus. 12] ${ }^{76}$. Moreover, coins were inventoried as well according to protocol ${ }^{77}$. In addition, more detailed building materials were later inventoried by Marian Morelowski. During his archaeological research of the remnants of the upper castles and territory investigation and his reconstruction of the original architecture analysis he measured brick sizes, profile brick forms and other parameters of building materials $^{78}$. Similarly, Jan Borowski investigated bricks and profile bricks as well

75 Zygmunt Meczyslaw Czaykowski measured St. Michael's Church (1943, KPC PB, f. 6, ap. 1, s.v. 58; 64-71; 4429-4430; 4578-4589, St. Philip and St. Jacob (1944, KPC PB, f. 6, ap. 1, s.v. 125-134), Chapel of St. Casimir in Vilnius Cathedral (1945, KPC PB, f. 6, ap. 1, s.v. 4013-4019; 119-124), Bell tower of Vilnius Cathedral (1945, KPC PB, f. 6, ap. 1, s.v. 2360, 2354-2355), St. Casimir (1940, KPC PB, f. 6, ap. 1, s.v. 343, 13907), St. Catherine (1941-1947, KPC PB, f. 6, ap. 1, s.v. 22-35), St. Nicholas (1938-1945, KPC PB, f. 6, ap. 1, 5843; 3588; with J. Zdanowicz, A. Konduralov, s.v. 72-76) churches. Some of his church drawings are now preserved in the Church Heritage Museum.

76 Even though there are no signatures to indicate who made this list of findings, hypothetically it could be attributed to the head of conservation works Jan Borowski. This hypothesis can be somewhat validated due to the similar attention he paid to building materials during his investigation in Trakai Island Castle. Spis Wykopalisk znależionych na Górze Zamkowej w Wilnie za okres 1933-1937 rok., in: LCVA, f. 52, ap. 10, b. 1186 (bylos lapai nenumeruoti).

77 Protokół. Zdawczo odbiorczy przedmiotów znalezionych w ruinach Zamku Górnego w Wilnie dnia 13 marca 1937 r., in: LCVA, f. 52, ap. 10, b. 1186 (bylos lapai nenumeruoti).

78 Materiały Marian Morelowski (1884-1963). J.W. Wilno Zamek dolny i górny, zamki polsko-litewskie notatki. Wypisy z literatury, rysunki, in: Archywum Polskiej Akademii Nauk, III234/112. 


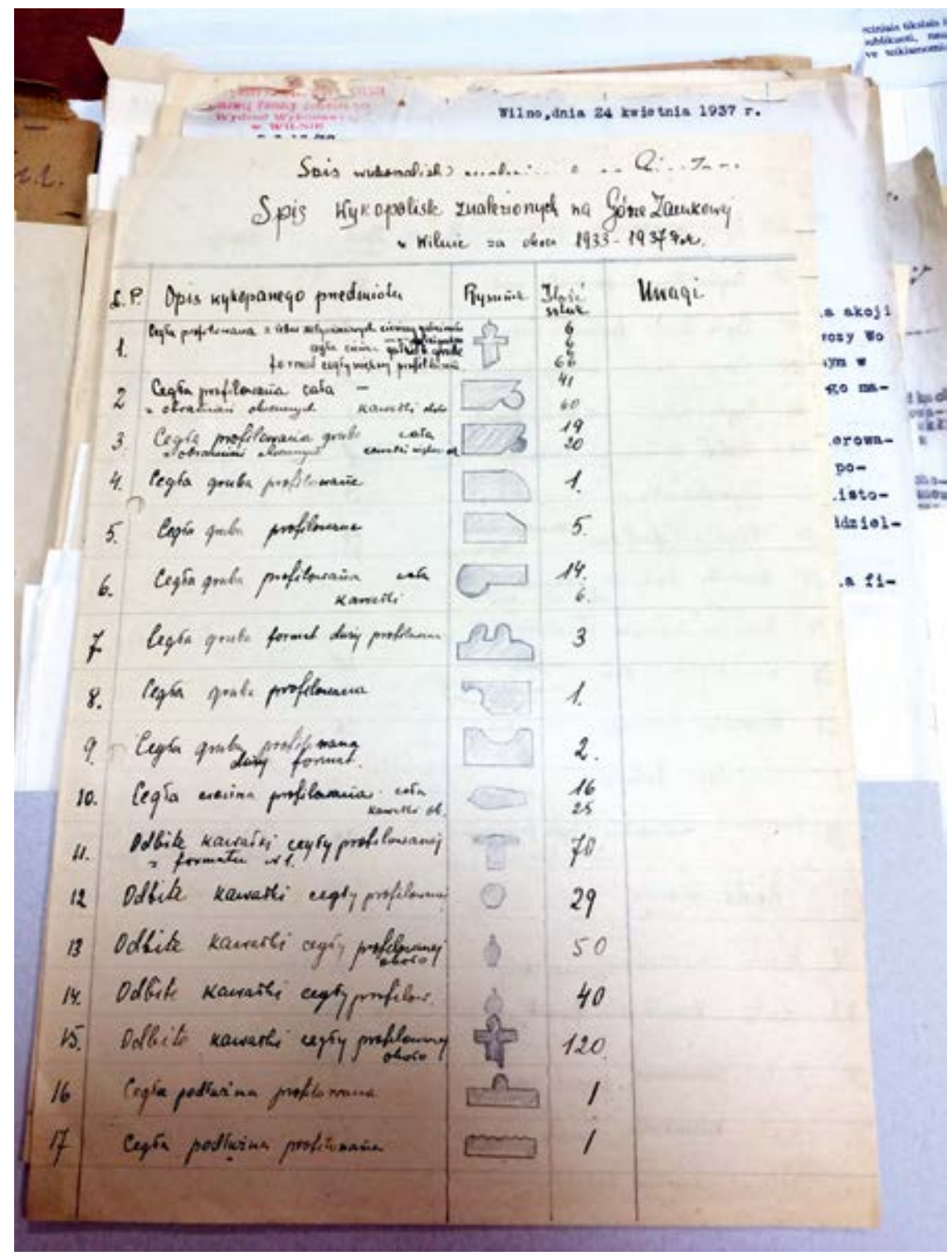

12.

[Jan Borowski], List of building material and archaeology findings during excavation in 1933-1937, LCVA, f. 51, ap. 10, b. 1186, [1. 1]
[Janas Borowskis], 1933-1937 m. atliktų kasinëjimų metu aptiktų statybinių medžiagų ir archeologinių radinių sąrašas 


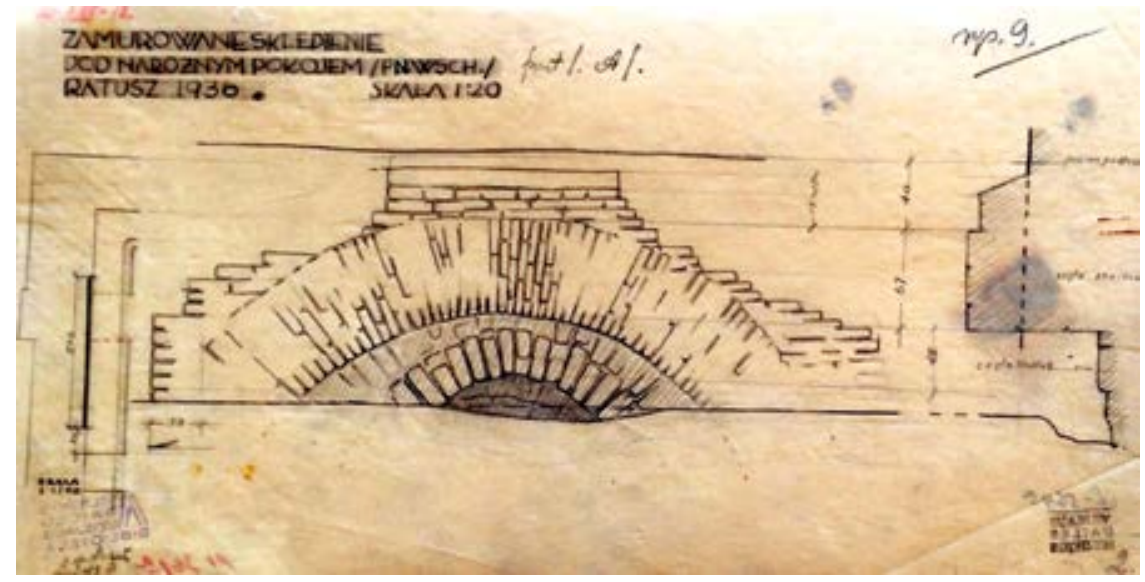

13.

Stefan Narębski, Vilnius Town Hall basement masonry survey of the arch, 1936, LNDM, V-54, A-564a

Stefanas Narębskis, Vilniaus Rotušès rūsio arkos mūro analizè, 1936

as other building materials (tiles, limes, stones, clay and other) of Trakai Island Castle ${ }^{79}$.

According to some archival documents it could be maintained that precise architectural investigations (non-intrusive and invasive) were made and the masonry walls were documented in the drawings. For instance, Stefan Narębski was one of the Vilnius Town Hall researchers with responsibility for adopting projects and restoration ${ }^{80}$. Among the remarkable quantity of his sketches and drawings preserved in the Lithuania Art Museum archi$\mathrm{ve}^{81}$ there are five documentation drawings of brick walls, and arches in the basement ${ }^{82}$ [illus. 13]. These drawings were probably made for conservation purposes, but as mentioned the architecture and masonry research was

79 Jan Borowski, op. cit., 1941, pp. 235-241.

80 Stefan Narębski did his project in 1928. Remont Ratusza, in: LCVA, f. 64, ap. 8, b. 189. Even the project of Stefan Narębski was made in 1928 but due to the lack of funds the detailed research and building conservation and adaptation processes only started in July 1936. Darius Pocevičius, 100 istoriniu Vilniaus reliktu, Vilnius: Kitos knygos, 2016, p. 742.

81 LNDM V-50, V-51, V-52, V-54.

82 [Stefan Narębski], Zamurowane Sklepienie pod narożnym pokojem, pn.wsch., Ratusz 1936, skala 1:20, in: LNDM, V-54, A-564a; [Stefan Narębski], Ratusz pokój 27 /od ul. Niemieckiej/ odkryty mur, 29 IX 1936, LNDM, V-54_A-564d; [Stefan Narębski], Zamurowane Sklepienie pod ścianą wschodnią/od ul. Wielkiej/ Ratsza 1936, skala 1:20, in: LNDM, V-54_A-564b; [Stefan Narębski], Mury i sklepienia w wykopie na fundament pod schody zewnętrzane gmachu Ratusza w Wilnie, skala 1-20, in: LNDM, V-54, A-564. [Stefan Narębski], Zamurowane Sklepienie pod narożnym pokojem, pd.zach. /od ul/ Niemieckiej/ Ratusz 1936, skala 1:20, in: LNDM, V-54_A-564c. 
carried out in 1936-1938 ${ }^{83}$. The architect analysed the measurements of the bricks as well ${ }^{84}$. As part of his project he analysed project drawings by Laurynas Stuoka Gucevičius, so it could be maintained that he also performed masonry stratigraphy research, because he had to find the ancient parts of the building and the reconstructions made in the 18 th century ${ }^{85}$. In addition, the measurement drawings of the Gate of Dawn made by Jan Borowski in 1932 show the fixed masonry wall of the basement and documentation on the sizes of bricks ${ }^{86}$ [illus. 14]. Moreover, in the survey drawings of Krèva Castle made in 1930, the engineer-architect analysed the masonry structure which he precisely documented ${ }^{87}$. As regards the drawings of Trakai Island Castle made by Jan Borowski and his assistants Kazimier Macur, Valentin Romanowicz and Aldonė Romanowiczienè, Witold Girdwayn it could be argued that the structure of the masonry walls structures was documented ${ }^{88}$.

Furthermore, it was the practice to document the uncovered masonry structures. For example, the basement arch of Vilnius Upper Castle was measured and drawn probably by Juozapas Kamarauskas ${ }^{89}$ [illus. 15]. Moreover, architectural structures were fixed during the digging for sewerage and other communication systems. For example, Julius Kłos made a drawing of an uncovered masonry structure in Pilies street in $1931^{90}$. Beside the situation plan the masonry was fixed from different positions. An

83 [Stefan Narębski], Mury i sklepienia w wykopie na fundament pod schody zewnętrzane gmachu Ratusza w Wilnie, skala 1-20, in: LNDM, V-54_A-564.

84 LNDM, V-54_A-564.

85 Remont Ratusza, in: LCVA, f. 64, ap. 8, b. 189.

86 [Jan Borowski], Zdęcia pomiarowe kaplicy Ostro Bramskiej wykonane pod czas odnowienia w 1932, skala 1:50, przekrój, in: KPC PB, f. 6, ap. 1, s.v. 407; [Jan Borowski], Zdęcia pomiarowe kaplicy Ostro Bramskiej wykonane pod czas odnowienia w 1932, skala 1:50, elewacja lylna, in: KPC PB, f. 6, ap. 1, s.v. 409; and other.

87 Jan Borowski, Ruiny zamku w Krewie roboty konserwacyjne w roku 1930, 25 IX 1930: in: KPC PB, f. 6, ap. 1, s.v. 1685 .

88 According to Jan Borowski's publication we know that he prepared a measurement drawing before conservation, restoration or other maintenance works and after. The drawings were made on a scale of 1:50 and architectural details on 1:20. Moreover "Every uncovered part of the castle's remains was measured and photographs were made”. Jan Borowski, op. cit., 1941, p. 233. Some drawings reveal this principle. Jan Borowski, Wieźa głownego korpusu ruin zamku na wyspie w Trokach po konserwacji w roku 1932, in: KPC PB, f. 6, ap. 1, s.v. 851; [Jan Borowski], [fragment of brick masonry], 10 VIII 1936, in: KPC PB, f. 6, ap. 1, s.v. 843; Jan Borowski, widok glowny ruin zamku wyspie w Trokakach po konserwacja w roku 1934, in: Stanislovas Mikulionis, 1935-1992, J. Borovskis. Trakų salos pilies kiemo galerijų rekonstrukcijos projektas, vaizdas po restauracijos, situacijos planai ir kt. Brèžiniai, 1934-1940, in: LLMA, f. 455, ap. 1, b. 314; and other.

89 [without signature, Juozapas Kamarauskas (?)], Mur konstrurcyjny,mur zachodni, in: KPC PB, f. 6, ap. 1, s.v. 982.

90 Juliusz Kłos, Plan murów odkopanzch przy ul. Zamkowej 28 paźdzernika 1931, in: KPC PB, f. 6, ap. 1, s.v. 413. 


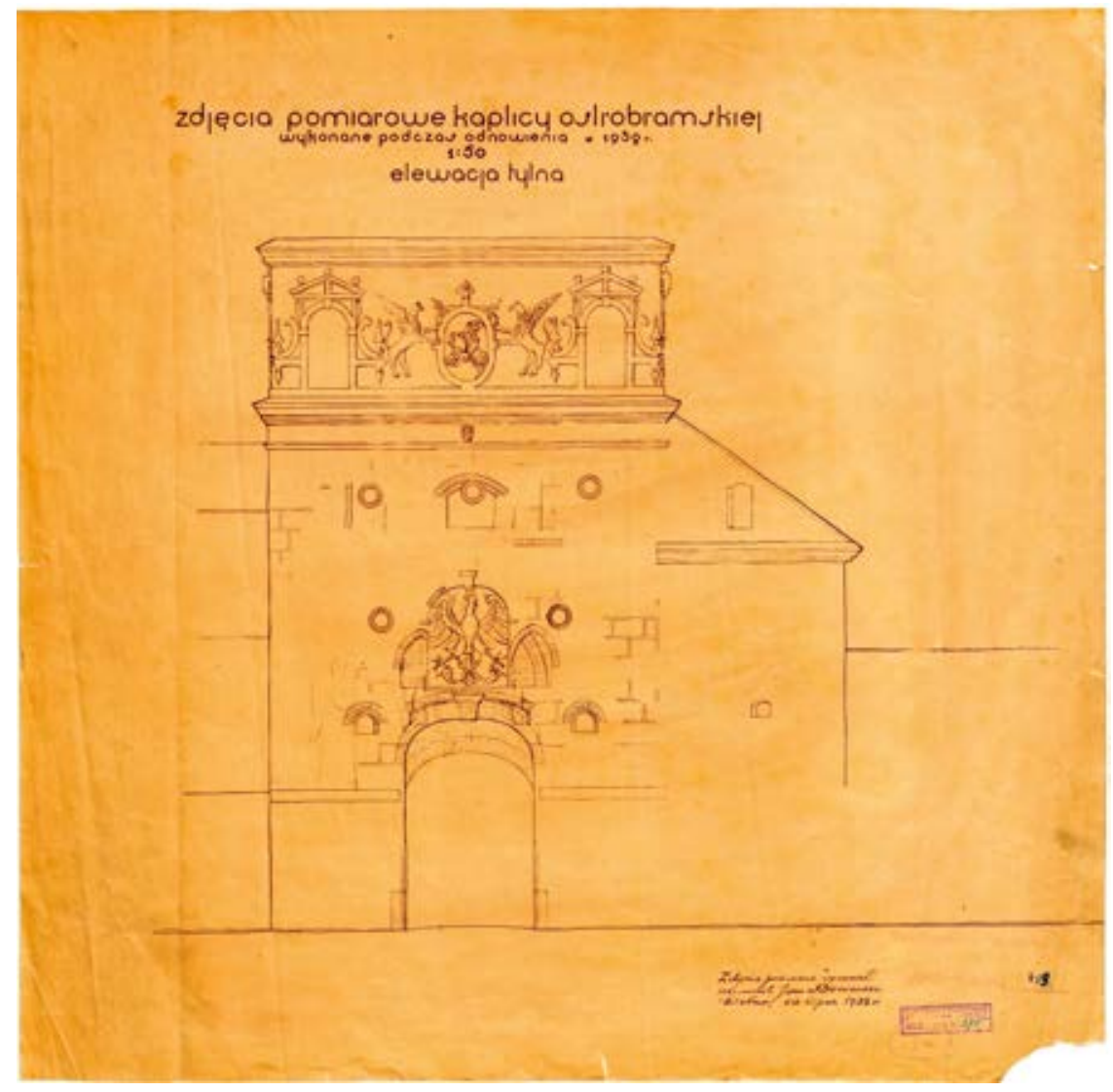

14.

Jan Borowski, Gate of Dawn, 1932, KPC PB, f. 6, ap. 1, Janas Borowskis, Aušros vartai, 1932 s.v. 409

inventory drawing of uncovered masonry in St. Magdaleny (now Šventaragio st.) in 1932 was done in a similar manner ${ }^{91}$.

According to account documents, payments for measuring, photography and inventory drawings were made. For example, the accounts show payments for the analysis of Vilnius Upper Castle: 200 zloty was paid for documentation works and an invoice from 21 September 1936 shows that the same amount was paid to the chief of conservation works, engineer-architect Jan Borowski ${ }^{92}$. Payments for photography of the Upper Castle 
investigation as well as conservation processes were made in parallel with inventory drawings and according to the accounts were made regularly during the 1930-1938 period $^{93}$, however only photographies could be find but other visual documents (as survey drawings) in archives are neglected.

\section{INSPIRATIONS BETWEEN LOCAL AND STATE}

Due to the research questions raised by this article, it is relevant to look in more detail at the relationship between local and state ideas of the research as well as at how research questions raised in Vilnius by intellectuals were reflected in the heritage investigation context of the Republic of Poland. As already discussed, the field research and investigations were organised mostly by institutions where strong and competent personalities worked. It should also be noted that scientific commissions as well as scholars and scientists from other institutions in Vilnius were involved in the research. There was also quite active communication between the ministry and other institutions from other Polish cities. The conservator frequently invited specialists to Vilnius for consultations, so there was a significant contribution to the research from them. They adapted the knowledge and ideas which they had acquired in western Europe to their research and heritage protection, while at the same time they tried to deepen the methods of applied research. Nevertheless, it is regretful, that due to the political and social changes after World War II these works were discontinued. Most of the researchers who worked during the interwar period retreated to Poland and the communication and collaboration in heritage research and preservation in Vilnius region stopped. However, there were some examples of efforts to renew contacts with the specialists who worked before the war, for example, the communication with Jan Borowski about the Trakai Island Castle conservation works ${ }^{94}$.

92 Zestawienie Rachunków, 1936 rugsèjo 21 d. in: LCVA, f. 52, ap. 10, b. 1186 (bylos lapai nenumeruoti).

93 Edita Povilaitytè-Leliugienè, op. cit., pp. 138-142.

94 Jan Borowski sent large photographs of his measurements and conservation works drawings. These valuable visual sources were received in 1955. According to Jan Borowski's letter to B. Krūminis (1957) Jan Borowski was invited to come to Vilnius and to consult about the conservation and restoration works in Trakai Island Castle. Stanislovas Mikulionis (1935-1992), J. Borovskio laiškas B. Krūminiui, in: LLMA, f. 455, ap. 1, b. 315, 1. 1. 


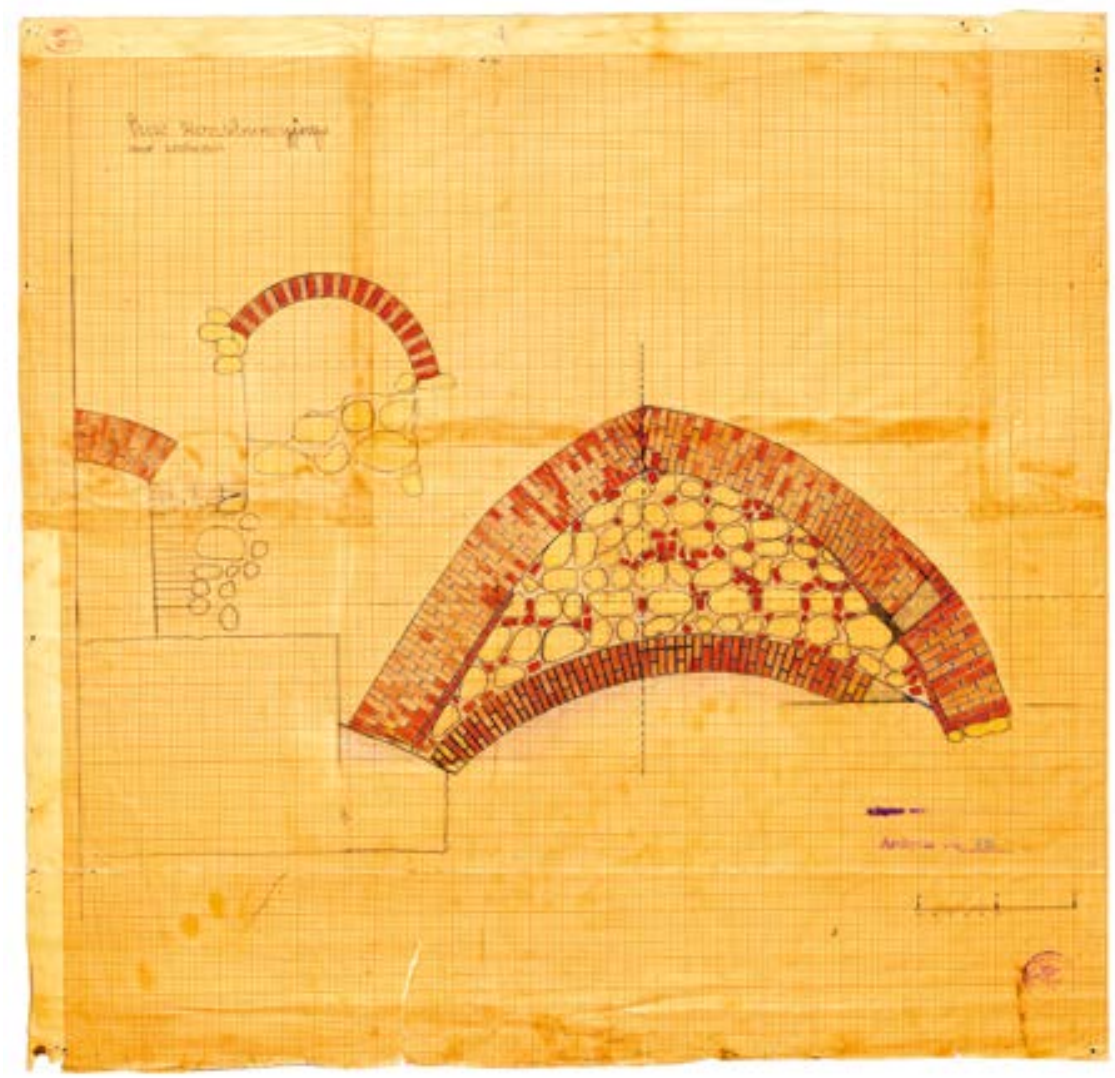

15.

[Juozapas Kamarauskas], The foundation arch of Vilnius Upper Castle Palace, KPC PB, f. 6, ap. 1, s.v. 982
[Juozapas Kamarauskas], Vilniaus Aukštutinès pilies rūmų pamatinè arka

\section{Conservator meetings: improvement of qualification}

Collegiate collaboration was one of the inspirations for research in the interwar period. This was similar to the general trend in the 19th-20th century of specialist meetings, congresses, conferences in Europe, Poland and Russia ${ }^{95}$. The main aim of such meetings were the discussions with different specialists.

From the time conservations offices were established in different regions of Poland, their institutional communications were through organised congresses. It is worth noting that the special Council of Conservators 
(Radą Konserwatorów) was established with responsibility for the formulation of opinion about heritage preservation and methods. This council was composed of regional conservators, the head of the Ministry of Religious Beliefs and Public Enlightenment and after 1928 the General Conservator. Their meetings were held once a year (or twice) and general and problematical questions of heritage maintenance and preservation were discussed and different cases were analysed. Paweł Dettloff summarised that these meetings were seen as the most important forum for heritage problems and created a platform for exchanges of opinions and created homogeneous norms of conduct ${ }^{96}$. During these congresses heritage preservation theories and technical practices were formulated and as Dettloff noted they discussed the same questions as today ${ }^{97}$.

Most of the discussion centred around heritage maintenance, conservation, restoration and reconstruction theories and practical problems. However, analysis of the congress protocols show that some research questions were touched on. For instance, discussions at the XII congress (Luck, 20-24 of September 1927) concluded that to carry out excavations and other research without the support of the conservator was impossible ${ }^{98}$; restoration could only be performed after comprehensive research, architectural details had to be measured and research of the architectural object's environment should also be performed ${ }^{99}$. There were also discussions about the survey of heritage objects. Due to Jerzy Remer's initiative to create a central office for inventory ${ }^{100}$ at the XIII and XIV congresses the necessity and methods of the registration of heritage objects ${ }^{101}$ as well as his prepared methodical publication were discussed ${ }^{102}$. For the XIV congress he presented the main rules and ideas:

96 Paweł Dettloff, “Z dziejów zjazdów konserwatorskich w Polsce. W stulecie I Zjazdu Miłośników Zabytków Ojczystych”, [online], p. 281, [cited 2019-11-15], https://www.nid.pl/upload/ iblock/2f5/2f5f6b5d3c79176a698adb60150f961b.pdf.

97 Ibid.

98 Protokol, p. 4, in: LCVA, f. 51, ap. 10, b. 1181 [without numbering].

99 Protokol, p. 7, in: LCVA, f. 51, ap. 10, b. 1181 [without numbering].

100 The Central Office of Inventory at Ministry of Religious Beliefs and Public Enlightenment was established on 11 June 1929.

101 Protokół XIII Zjazdu Rady Konserwatorów w dn. 25 i 26 października 1928 roku w Warszawie, Protokół XIV Zjazdu Rady Konserwatorów w dn. 26, 27 i 28 października 1929 r. w Poznaniu, in: LCVA, f. 51, ap. 10, b. 1188, p. 86, 96.

102 Jerzy Remer, "Program inwentoryzacji zabytków sztuki w Polsce”, in: Ochrona Zabytków, No. 1-4, 1930/1931, pp. 415-416. 
1. System of inventory; the question is, if the inventory have to be as cathalogue, register with iliustration, or more like to monography.

2. Determine the period which would embrace the inventory (e.g. from 10th century to epoch of Romantism).

3. To found the folk art department based on examples of the newst Czech publications.

4. Survey drawings (architectural) and photographies, then relation of illiustrative material and written representation as well as architectural scale survey.

5. Presentation of drawings (sketches) beside of photograhies. ${ }^{103}$

The ideas for the inventory were based on German, Austrian and Czech methods (as he mentioned G. Dehio, Handbuch der Kunstdenkmäler, Konsttopographie). The inventory needed to be synthesised ${ }^{104}$. General Remer's letter detailed what information was to be on the survey drawings and what type of drawings were to be presented to the Central Office of Inventory ${ }^{105}$. The survey drawing of Vilnius heritage presented previously illustrates these methods.

The VIII Congress of Conservators in Warsaw discussed the necessity of public discussions and presentations about heritage theories and problems as well as the preparation of a specialised publication. For example, Vilnius Architect Association (Stowarzyszenie Architektów w Wilnie) initiated the organisation of an Exhibition of Architecture. A letter to the Art Department of Vilnius Voivodeship office (17 October 1927) signed by Juliusz Kłos said that it was planned to present 3 themes: contemporary architecture where it was planned to exhibit projects, photographs of buildings and models; the second theme was historical architecture where it

103 “1. System inventoryzacji; zagadnienie, czy inventaryzacja ma być katalogiem, rejestrem ilustrowanym, względnie zbliżać się do ujęcia monograficznego.

2. Ustalenie ram epok, a których powinna zamknąć się inwentaryzacja / X wiek aż po epokę romantyzmu włacznie/.

3. Właczenie działu sztuki ludowej wzorem ostatnich publikacji czechosłowackich.

4. Zdęcia pomiarowe/architektoniczne/ oraz fotografje, a w tem stosunek materjału ilustracyjnego do opisowego oraz skala zdjęć architektonicznych.

5. Wprowadzenie rysunków odręcznych poza właściwemi zdjęciami”. Protokół XIV Zjazdu Rady Konserwatorów w dn. 26, 27 i 28 października 1929 r. w Poznaniu XIV protocol, in: LCVA, f. 51, ap. 10, b. 1188, p. 96.

104 Ibid.

105 Jerzy Remer, W sprawie nadsyłania zdjęć pomiarowo-architektonic znych na Powszechną Wystawę Krajową w Poynaniu, 20 lutego 1929, in: LCVA, f. 51, ap. 10, b. 1188, p. 99. 
was planned to present inventory drawings and surveys as well as photographs and the third theme was industrial heritage ${ }^{106}$.

This congress was seen as an opportunity for conservators to improve their qualifications as they could implement or ameliorate the heritage research and preservation methods in their supervised heritage objects based on the experiences of others. However, confirmation of this statement would need deeper research; nevertheless the problems discussed during these meetings applied in general to heritage objects. Therefore, this meeting had scientific aims for creating better heritage investigation and preservation methods ${ }^{107}$.

Comparative analyse of research questions and methods in other conservator offices

Due to the protocols of the Conservators Council, heritage preservation questions were discussed more often, however, it could be maintained, that research problems were also briefly considered. According to the 1927 meeting, the research assignment for Lubart Castle was formulated for Vilnius Upper Castle (research programme in 1930), Trakai Castle and other objects.

Furthermore, it could be maintained that problems and methods of research in Vilnius partially reflect the general tendencies of the state. As the analysis of the Polish Architecture Institution's report of the period (April 1929-April 1930) reveals that Vilnius region as well as the region's conservator were included in the activities and furthermore the personalities who were responsible for the inventory, research section or publication later worked in Vilnius (for example, example Piotr Bogdziewicz, Witold Kieszkowski among others $)^{108}$. Thus, it could be claimed that some ideas such as inventory methods were formulated in Vilnius and later, through Jerzy Remer, the Central Office of Heritage Inventory was created in Warsaw in 1928. The research of the castles was partially related with the general state tendencies which were overseen by Conservator Stanisław Lorentz who held this post after Jerzy Remer. The publication of the research

106 Stowarzyszenia Architektów w Wilnie do Kierownika Oddziełu Sztuki przy Urzędzie Woj. W miejscu, za prezydium Stowarzyszenia Architektów w Wilnie prezes J. Kłos, 17 X 1927, in: LCVA, f. 51, ap. 10, b. 1181 [without numbering].

107 Paweł Dettloff, “Z dziejów zjazdów konserwatorskich w Polsce”, p. 284.

108 Sprawozdanie roszne z działności Zakładu Architektury Polskiej P. W. za czas od 1. IV. 1929 r. do 1. IV. 1930 r. in: LCVA, f. 51, ap. 10, b. 1192, pp. 33-43. 
in special journals was also related with the general Conservators Councils theoretical tendencies which were extended by Marian Morelowski, who due to the creation the Art History Section at Vilnius Friends of Science Society and new journal publication urged other scholars and scientists to carry out heritage research projects. The synthetic works of architecture were mostly based on stylistic analysis methods.

\section{INDIVIDUAL PRACTICES}

Beside institutional regulation the individual practices of architectural research reveal much wider aspects and deeper investigations of heritage objects.

\section{Juliusz Kłos}

Juliusz Kłos was one of the most active architects, researchers and restorers in Vilnius and the region. He created a valuable base of architectural applied scientific researches, heritage inventory and restoration ${ }^{109}$. Kłos was passionate about heritage scientific research and preservation problems; his personal library, scientific papers studied and books all reflect this as does his work ${ }^{110}$. He admired Alois Riegl and other heritage preservation representatives of the Vienna School, Cezar Boito, Cornel Gurlitt, Gustav Giovani. According to Cornel Gurlitt’s ideas Juliusz Kłos was very attentive to an architectural object's history as well as to the archaeological and technical architecture data.

The methods which Juliusz Kłos created and used are partially revealed in his paper Masonry of the University (Dzieje Murów Uniwersyteckich) ${ }^{111}$ and the study plans of the evolution of the university complex ${ }^{112}$ as well as the other publications, and architectural researches performed by him. First of all, he noticed that the masonries of the Vilnius University

109 Nijolè Lukšionytė-Tolvaišėnè, op. cit., p. 73; Józef Poklewski, "Prof. Juliusz Kłos (1881-1933)", p. 286.

110 Janina Bielinienè, „Ką apie prof. J. Kłosą pasakoja jo knygos“, in: Vilniaus architektūros mokykla XVIII-XX a., Vilniaus akademijos darbai, t. 2, Vilnius: Vilniaus dailès akademijos leidykla, 1993.

111 Dzieje Murów Uniwersyteckich, in: LVIA, f. 1135, ap. 12, b. 71; Juliuszas Kłosas, Universiteto mūrų istorija, iš lenkų kalbos vertė St. Pinkus, in: Dokumentų byla apie Vilniaus Universiteto pastatų ansamblį (universiteto, Balio Sruogos, Gorkio, Tallat-Kelpšos g-vès) Atr-65a, 1921-1971, in: KPC PB, f. 3, ap. 1, b. 448.

112 Dokumenty prof. J. Kłosa, in: LVIA, f. 1135, ap. 12, b. 17. 
complex itself could reveal the history of evolution which could complicate the stylistic analysis and make it difficult to date them due to intensive reconstructions by different builders and in different periods. Kłos poetically wrote: "in these masonries could be visible the unforgettable stony chronical of Vilnius University"113. So, he started his architectural research with a detailed analysis of historical archival sources. As a result of his investigations he emphasised the significance of critical thinking and analytical analysis of written documents as well as comparative studies with the current situation and plans of a building. Moreover, he identified the main trap of archival messages and sources of a building's history which are related with laconic, hardly identifiable, non-detailed information as well as the difficulties of sourcing archival documents.

The second step of his research emphasised an analytical and comparative analysis of historical, cartographical, and iconographical plans. However, according to the architect this analysis would be incomplete without the investigation of the building or building complex itself. So, historical architectural research according to Juliusz Kłos should be an analytical comparative investigation of historical written, visual sources and the technical construction (such as the constructions of the roof, building methods etc.), architectural styles and building characters of different periods. As he noted the masonry itself is a document. However, due to differences in the building periods, reconstructions and maintenance, the architectural researcher should comprehensively analyse the architecture history and understand not only the differences in the style and decorative elements, but should also understand the mentality of the builders, building technologies (as constructions, parameters of the sizes, layouts and other), building materials (bricks sizes, tales and other), technology methods of the building bricks etc.

As the third step of architectural research Juliusz Kłos used reconstructive methods. He prepared the reconstruction plans of the university building in different periods (16th, 17th, 18th, 19th centuries and 1921). This analysis revealed the evolution of the university complex. However, according to Juliusz Kłos these architectural investigation principles reflected only partially the evolution of the building complex. So, it could be 
concluded that the architect encouraged deeper and more comprehensive architectural research methods.

Juliusz Kłos’ architectural research methodology widened with the Vilnius Cathedral investigations. As the research programme prepared by the architect revealed, due to the critical condition of the building and difficult architectural constructions as well as the general condition of the grounds and environment it was not possible from the point of view of heritage research to understand the architecture itself or the archaeological data. But the incorporation of other sciences is very important for the best solutions of heritage preservation ${ }^{114}$. In addition, Juliusz Kłos emphasised the important of architectural research documentation and scientific reports.

\section{Jan Borowski}

Jan Borowski was inspired by Juliusz Kłos and became interested in heritage preservation. He came to Vilnius in 1925 and started his career as a restorer with architecture inventory and surveys as well as with the conservation and restoration projects of Vilnius sacral heritage (St Casimir’s Church among others). If Juliusz Kłos’ architectural research methodology was of the more humanitarian type ${ }^{115}$ so then Jan Borowski was more of a technical researcher of architecture. As Marcin Gawlicki noted having analysed Jan Borowski's works after World War II in Gdansk the architect was mostly concerned with technical analysis and technical conservation, restoration and rebuilding problems ${ }^{116}$. Even though he worked in SBU and gave lectures on architecture history, heritage preservation, his later published works represent him as delving deeply into historical architectural construction investigations ${ }^{117}$.

114 Protokuły posiedzienie Komisji Techniczny, in: LVIA, f. 1135, ap. 12, b. 96.

115 This aspect is revealed in his published guides about Vilnius and Vilnius region. Juliusz Kłos, Wilno. Przewodnik krajoznawczy Juliusza Kłosa prof. Uniwersytetu St. Batorego. Wydanie trzecie poprawione po zgonie autora, Wilno: Wyd. Wileńskiego oddziału Polskiego towarzystwa turystyczno-krajoznawczego, 1937.

116 Marcin Gawlicki, Zabytkowa architectura Gdanska w Latach 1945-1951. Ksztaltowanie koncepcji konserwacji $i$ odbudowy, Gdańsk: słowo/obraz terytoria, 2016.

117 Jan Borowski, Historia architektury powszechnej, cz. 1: Architektura renesansowa I barokowa we Włoszech, Gdańsk: Wydawnictwo Uczelniane Politechniki Gdańskiej, 1964; Idem, Ochrona zabytków, Gdańsk: Politechnika Gdańska, Państwowe wydawnictwo naukowe, 1954; Idem, "Dachy Gdańskie. Rekonstrukcje”, in: Ochrona Zabytków, 1949, No. 1. 
Due to the lack of Jan Borowski archival documents from his Vilnius period as well as his later personal documents ${ }^{118}$, we can surmise that his architectural research methods could have been revealed in his scientific publication of Trakai Island Castle research and conservation prepared in $1941^{119}$. The publication represents all the heritage management works carried out from 1929 to 1940 which Jan Borowski organised and supervised. Undoubtedly, the architectural research principles were specific and were doubtless used in his research processes while he worked in Vilnius Upper Castle.

Thus, the architectural heritage research methods attributed to Jan Borowski were based on the precise collection of data at every stage of the research process as well as the drawings of every excavated part, drawings before and after conservation was carried out ${ }^{120}$. In general, a heritage investigation started with heritage object cognition questions and a detailed inventory of the castle's masonry as well as survey drawings. He excluded a few important stages of the research made in Trakai Island Castle: first, the excavation of some architectural structures for a better understanding of the whole castle's layout (1935), second, investigations of the masonry and basements, as well as the environment around the castle (1938).

Jan Borowski's heritage investigation methods ranged from recognising the current situation and historical analysis to scientific visual reconstructions. He first made an analysis of the historical architectural evolution of the former castle's structure, second, he analysed the castle's environment and discussed the strategical situation and, third, he carried out a technical investigation of the building technologies and materials and

118 The information presented in art historian, Ciemnołoński Janusz' articles that Jan Borowski's personal documents were preserved in Gdank Polytechnical university were not confirmed. Despite the efforts of this article's author the whereabouts of these documents is still unknown. Only some sources and graphic materials are preserved in Vilnius archives and some biographical documents are in Gdank Politechnical University's archive. Janusz Ciemnołoński, Jerzy Stankiewicz, "Architekt Jan Borowski (1890-1966)", in: Kwartalnik Architektura i Urbanistika, teoria i historia, Warszawa, 1990, No 3-4; Janusz Ciemnołoński, Jerzy Stankiewicz, „Jan Borowskiarchitekt i konserwator“, in: Konserwator i zabytek. In memoriam Jerzego Remera, Warszawa, 1991, p. 152-162; Janusz Ciemnołoński, "Jan Borowski - pierwszy polski wojewódzki konserwator w Gdańsku”, in: Pism PG, 1995, No. 7 (18); Borowski Jan. Wykaz prace naukowych i zawodowych inż. architekta Jana Borowskiego, in: Archive of Gdansk Politechnical university. WA_120_22; Document of Jan Borowski, in: Archive of Gdansk Politechnical university, NLP_130_138_6.

119 Jan Borowski, op. cit., 1941, pp. 199-242.

120 Most of the principal drawings were sent by architect after WWII in 1952; KPC PB, LLMA, in 1955: Jan Borowski, in: KPC PB, f. 6, ap. 1, s.v. 848, 851; Jan Borowski, in: LLMA, f. 455, ap. 1, b. 514 . 
attempted to date the different stages of the masonry. He based his research on stylistic comparison methods and used the works of the best-known western European researchers as well as those of local researchers (for example, Violet-le-Duc, Benoit, Enlart Camille, Heiz Clasen, M. Krol, Thule, Z. Hendel, St. Lorentz, M. Morelowski, W. Szukiewicz). It should be noted that he used applied architectural materials analysis. He investigated the technical characteristic of the building materials and also discussed their uses in the castle's building processes. As he noted: "this research would be worthy material for theoretical reasons, while wider investigation works will examine the technology of medieval building materials and building in general as well as for the further research of Trakai castle"121. In addition, Jan Borowski raised hypothetical questions about why the castle's builders selected such architectural and defensive forms and structures. His retrospective and reconstructive methods disclose that he was attentive not only to architectural forms, but he also combined theoretical problems with practical analysis of environmental and strategical defensive possibilities.

\section{Marian Morelowski}

Marian Morelowski's art historian methods of architecture research differ from those of Juliusz Kłos and Jan Borowski. According to Nijolè Lukšionytė, Marian Morelowski and Juliusz Kłos represented the academic art historian trend during the interwar period in Vilnius ${ }^{122}$. He came to Vilnius in 1930 and actively started his scientific researches there as well as trying to create a more active community. Morelowski was involved in different commissions which discussed the heritage problem question from the theoretical perspective and was known as someone who understood problems in the wider cultural and historical contexts. His later works reveal that he actively collected archaeological, architectural, historical and much other data which he generalised in his later research papers.

Andzej Kozieł noted that Marian Morelowski's works in Vilnius brought many changes to his career and his research efforts. He was very active in trying to find out the national approach to the local characteristics of architectural and art heritage. His interests ranged from art history

121 Jan Borowski, op. cit., 1941, p. 234.

122 Nijolè Lukšionytė-Tolvaišienè, op. cit., p. 73. 
problems $^{123}$ to urban analyses and the evolution of Vilnius city in the 14th15 th and later in the 17 th centuries as well as the old structure plan reconstruction of Vilnius ${ }^{124}$. Marian Morelowski synthesised all archaeological, architectural, historical and urban research data from the 1920s and the $1930 \mathrm{~s}^{125}$. Moreover, he researched separate architectural heritage objects such as the church of St Ana, Subačius gate and Trakai Island ${ }^{126}$. He also analysed the characteristics of the style and evolution of a building. He prepared a publication about the peculiarities of Baroque Vilnius heritage ${ }^{127}$. The research sphere of Marian Morelowski’s research was Władzsław Tatarkewicz which embraced the lands, architecture and art research of the Lithuanian Grand Dukes and used comparative stylistic analysis methods to analyse the genesis of forms and problems of local origin ${ }^{128}$.

Analysis of Marian Morelowski's manuscripts and research documents reveal that his architectural research crossed from the humanitarian sphere to technical analysis. In order to gain a deeper understanding of architecture he started to investigate the characteristics of building materials such as the sizes of bricks, the specifics of profile bricks, archaeological findings data, tiles, constructive building fragments and structures ${ }^{129}$. As Napaleonas Kitkauskas noted, Marian Morelowski used new methods at

123 For example, he prepared his habilitation work from an analysis of the crown's treasure.

124 Marian Morelowski, Urbanistyka Wilna XIV i XV.; Jūratė Markevičienė, „Pamiršta hipotezé", p. 30-45. Later he analyze the urban development of Wroclaw. Marian Morelowski, "Rozwój urbanistyki Wrocławia przed kolonizacją z lat 1241-1242”, in: Sprowozd. Wroct. Tow. Nauk, 1951; Idem, "Rozwój urbanistyki Wrocła w wiekach średnich I w dobie nowożytnej do r. 1807 [w. wyd.:]”, in: Wroctaw. Rozwój urbanistyczny, Warszawa, 1956; Idem, Vilnius prieš 1655 metus. Rekonstrukcinio plano 318 numeriu paaiškinimas, vertimas iš lenkų kalbos, Vilnius, 1961, rankraščio kopija: Vilniaus regioninis valstzbės archyvas (toliau - VRVA), f. 1019-11-4358.

125 Materiały Marian Morelowski (1884-1963). J. W. Wilno Zamek dolny i górny, zamki polsko-litewskie notatki. Wypisy z literatury, rysunki, in: Archywum Polskiej Akademii Nauk, III234/112. According Marian Morelowski manuscript “Zarzecze - najstarsze Wilno” art historian J. Markevičienė discussed and evaluted his research methods; Jūratė Markevičienė, „Pamiršta hipoteze்“, pp. 30-45.

126 Marian Morelowski, "Geneza stylu kościoła św. Anny i formy bramy Subocz w Wilnie”, in: Prace i materiaty Sprawoyd. Sekcji Hist. Sztuki Tow. Przyj. Nauk w Wilnie, z. 4, 1935; Idem, "Wschód i yachód a zamku Trockim na wyspie", in: Prace i materiaty Sprawoyd. Sekcji Hist. Sztuki Tow. Przyj. Nauk w Wilnie, z. 4, 1935; Idem, "Zamek najeziorny Trocki a źródła jego formy zachodnie I czarnomorskie", in: Sprawozdania z posiedzień Towarzystwa Nauk Warszawskiego, Wzdz. 2: Nauk historicznych, spolecznych I filozoficynzch, Warzawa, 1947, pp. 47-56.

127 Marian Morelowski, "Problemy wileńskiej architektury barokowej”, in: Prace $i$ materiaty Sprawoyd. Sekcji Hist. Sztuki Tow. Przyj. Nauk w Wilnie, z. 4, 1935.

128 Nijolè Lukšionytė-Tolvaišienè, op. cit., pp. 68-69.

129 Materiały Marian Morelowski (1884-1963). J. W. Wilno zamek dolny i górny, zamki polsko-litewskie notatki. Wypisy z literatury, rysunki, in: Archywum Polskiej Akademii Nauk, III234/112. 


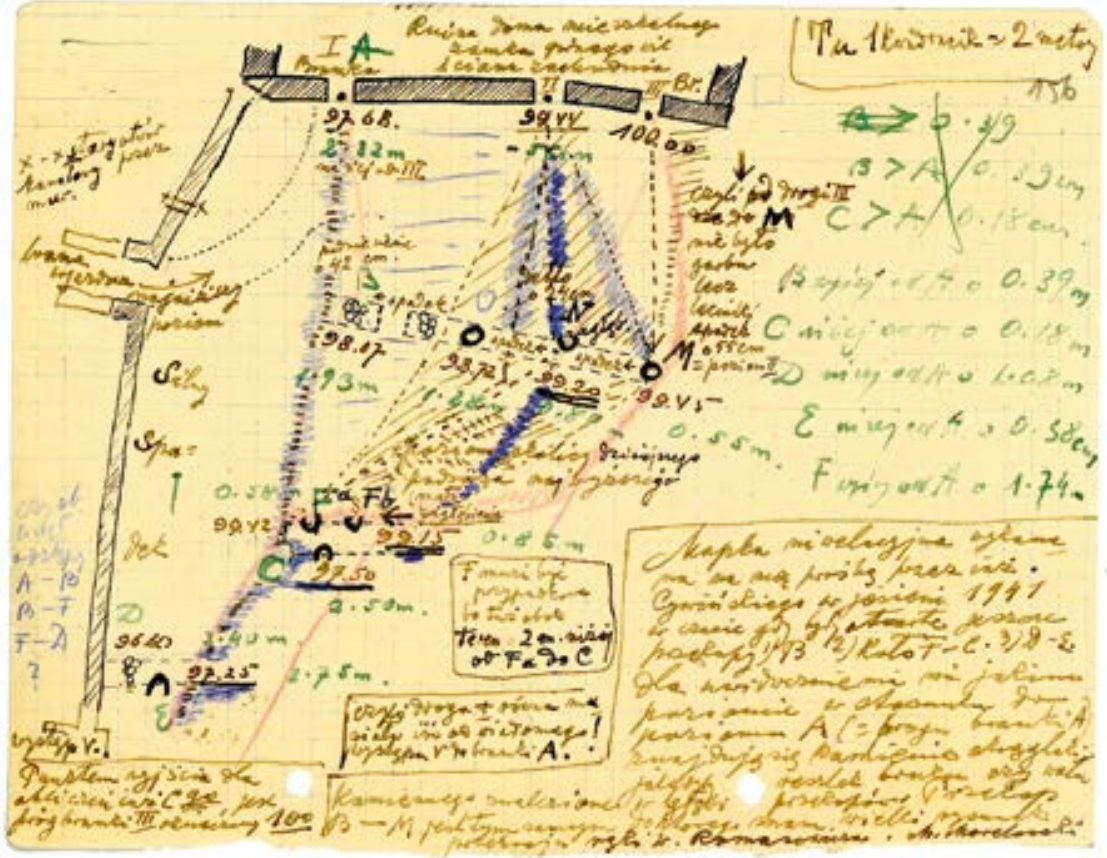

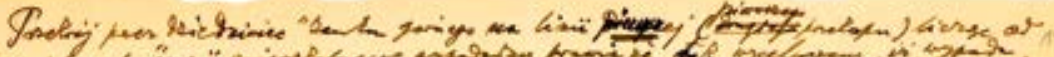

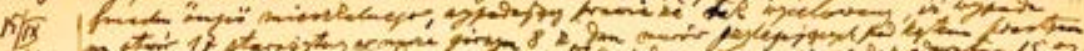

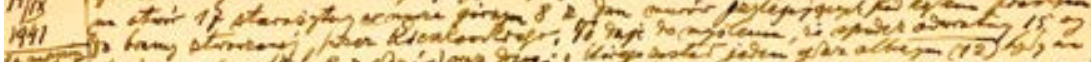

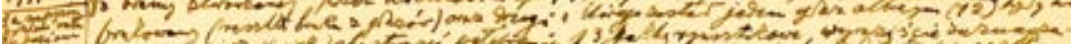

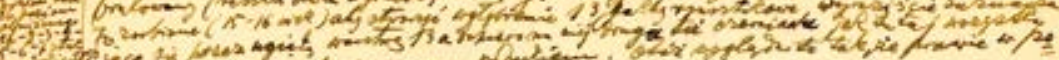

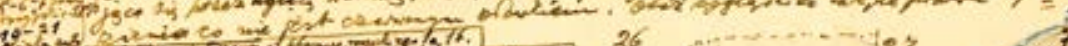

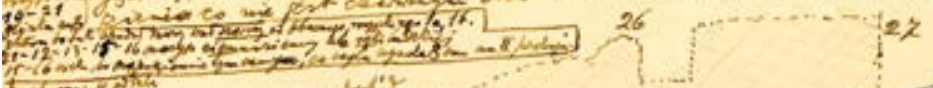

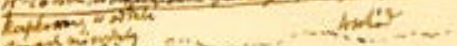
$405-26=325$

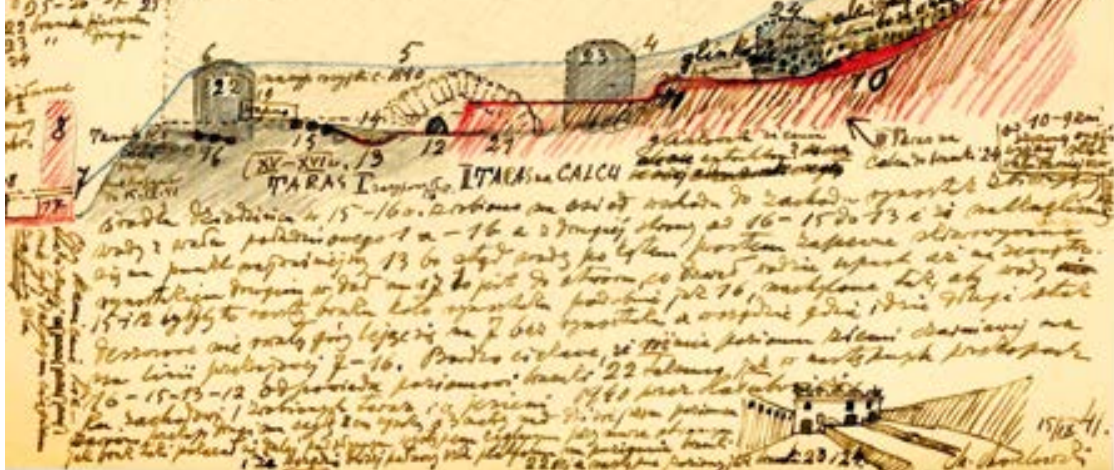

16.

Marian Morelowski, Manuscript of Vilnius Upper Castle investigation, Archyvum Polskiej Akademii Nauk, III234/112, 1. 156, 158.
Marianas Morelowskis, Vilniaus Aukštutinės pilies tyrimų manuskriptas 
that time in his research and reconstructive study of Vilnius plan before 1650. He analysed the masonry and tried to date different buildings with a comparative analysis of contextual analogous studies ${ }^{130}$. Moreover, this study also reveals his research methodology from a detailed cartographical and historical plan analysis which is compared with field research data and reconstructive hypothesis. He stated that it was not enough to present an analytical investigation and compare data, there must also be a mathematical and logical analysis ${ }^{131}$.

He prepared the report of the archaeological investigation of Vilnius Castle territory which he observed for a decade and here he used not only the representation of data, but also analytical contextual research methods ${ }^{132}$ [illus. 16]. In his research of the Vilnius plan and structure formation before the defensive city wall was built in the middle of the 15th century he cited very different scientific (written sources, historiographical material, integrated history, archaeology, architecture history, geography, geology, urban and geomorphology methods) data and methods which he compared and analysed ${ }^{133}$. Marian Morelowski investigated the layout structure of the city, the directions of exterior roads and the network of streets as well as the location of the oldest buildings and the axis of the city. He also talked about the ancient living tradition and relations between the castle and settlement as well as the defensive methods used. He emphasised the importance of nature as relief and the water (river) system for the formation of general city structures. Some of his hypotheses were proved as correct according to later new findings ${ }^{134}$, some not ${ }^{135}$. As Povilas Reklaitis noted the art historian's works were hasty and were based on weak arguments ${ }^{136}$, but the complex methodology which he used was very modern and his knowledge was very progressive for that time.

130 Napaleonas Kitkauskas, „Vilniaus pilys Mariano Moreliovskio (1884-1963) tyrimuose“, in: Vilniaus istorijos metraštis, 2007, t. 1, p. 115.

131 Marian Morelowski, op. cit., 1961.

132 Marian Morelowski, Raportas apie archeologinius kasinėjimus Aukštutinės ir žemutinės pilies teritorijoje, referas, Vilnius, 194010 13, in: LLMA, f. 81, ap. 1, b. 17, 1. 2-9.

133 Jūratè Markevičienè, „Pamiršta hipoteze்“, pp. 30-45.

134 Ibid., p. 31.

135 Napaleonas Kitkauskas, op. cit., p. 97-116; Jūratė Markevičienè, „Pamiršta hipotezė“, pp. $30-45$

136 Povilas Reklaitis, „Morelowski Marian“, p. 269. 


\section{Zygmunt Mieczyslaw Czaykowski}

Zygmunt Mieczyslaw Czaykowski was also involved to some extent with heritage research. However, he only came to Vilnius in 1938, so the most important sketches of his manuscripts and an impressive number of drawings, which are now preserved in different institutions, were made during World War $\mathrm{II}^{137}$. The researcher of his written material, Birute Rūta Vitkauskienè, noted that his research methods ranged from visual to logical analysis methods, which were close to the main research aims of Marian Morelowski, which was to find the oldest buildings and urbanistic structure as well as to understand the evolution of the city compared to the current layout of the city ${ }^{138}$.

Zygmunt Mieczyslaw Czaykowski worked as an architect, but alongside that he was very keen to research the oldest layers of medieval Vilnius. He sought to identify and to reconstruct the oldest structure of Vilnius and its buildings. His research methods therefore differed from others because he was looking for the oldest masonry in basements, engineering systems, and he observed every ground works in the city. He thus used fragmented data systemisation and accumulation methods which he incorporated into general contexts. According to the memoir of Vladyslavas Mikučianis, Czaykowski made accurate drawings of all the data he found, he systemised it; he also marked and localised data in the city plans and this was followed by extensive scientific comments and analyses ${ }^{139}$.

Like other researchers he was very attentive to written sources as well as iconographical materials. He analytically investigated every word in the oldest archival manuscripts ${ }^{140}$ and the visual sources and compared them with field and underground (of basements and other) researches ${ }^{141}$. Czaykowski performed many non-intrusive investigations, however it should be remembered that during that period far fewer reconstruction and maintenance works were carried out in the basements of Vilnius old town, so many more of the oldest structures could be seen than could be seen today.

137 KPC PB, Valdovų rūmai, Bažnytinio meno muziejus, LNDM.

138 Birutė Rūta Vitkauskienè, „Iš Zygmunto Mečislavo Čaikovskio rankraščių“, in: Acta Academia Artium Vilnenesis, t. 57, Vilnius: Vilniaus dailès akademijos leidykla, 2010, p. 127.

139 Vladislovas Mikučianis, Norejjau dirbti Lietuvoje, Vilnius: Vilniaus dailès akademijos leidykla, 2001, pp. 50-51.

140 Birutė Rūta Vitkauskienė, „Pamirštas Vilnius. Iš Vilniaus tyrinëjimų istorijos“, in: Lietuvos pilys 200\%, Vilnius: Vilniaus pilių valstybinio kultūrinio rezervato direkcija; 2008. pp. 14-20.

141 Birutė Rūta Vitkauskienė, „Iš Zygmunto Mečislavo Čaikovskio rankraščių“, p. 126. 
He also used analogous research methods by comparing heritage objects built in the same period. So, the statistical data was important to him as well. His reconstructive drawings reveal that he was interested in nature and geological structure changes ${ }^{142}$.

From the short presentation of those researchers who used architectural heritage investigation methods we could claim that the individual practices were very complex. The principles reflected a modern heritage investigation mentality as well as an understanding of the different layouts important for contextual heritage recognition. It can be noted that these four researchers partially used or even became acquainted with western European research methodologies presented in the best known - of that time - theoretical works. They formed their individual research principles and methods to express their understanding and findings of the architectural heritage object, building complexes or urban development and many other questions.

\section{Conclusion}

From the above discussion it can be concluded that while investigations into the quantity and quality of heritage research backed by the institutions, the lack of state support hindered the work. Nevertheless, due to the enthusiasm of the conservators, architects, art historians and others the architectural heritage research methods and quality can be appreciated as very deep, scientifically based and complex. The investigations carried out by heritage researchers, while based on western European theories, methods and ideas, were also based on individual practices and due to each researcher's personal interest in different aspects of heritage research a wide methodological scientific research platform was created in Interwar Vilnius and region. Nevertheless, it must be emphasised that these processes were interrupted by the political situation and World War II. On the contrary if some discussions show that there was poor continuity of these works in Lithuania and Poland, deeper analysis reveals that many ideas and investigation methods were extended. These are worthy of further discussion. 
Furthermore, the analysis of the architectural heritage research programmes revealed that the scale of the research depended greatly on institutional regulation, the condition of the building and state finances. The competences of the researcher and general understanding of the needs for better cognition and recognition of a heritage object's history, building specifics, constructions, conditions, technological maintenance problems and other factors were however, also important. The discussion on inventory problems reveals that one person's initiative could be the base for establishing a state inventory institution.

The heritage investigations in Interwar Vilnius were based on methods ranging from comparative analysis to technical research. Historical archival documents were analysed precisely, analytical methods of iconographical, plans, cartographical and other visual documents were also used. These analyses were further supplemented by logical, analytical and mostly mathematical reconstruction of the primary object's views, structures and constructions. Therefore, intrusive and non-intrusive field investigation methods occupied a very important role during the heritage research processes in Interwar Vilnius. However, the lack of research documentation or the loss of such documents during the war and the disappearance of a researcher's personal documents hindered the presentation and analysis of this paper and the research performed. There are only a few archival sources on this interesting and rich context of this research field in Interwar Vilnius.

And finally, heritage research and heritage preservation practices in Vilnius were treated as part of Poland's heritage research questions and problems, context and discussions of the best heritage preservation practices. The change of the main region conservators, annual conservators meetings as well as the different backgrounds, knowledge and practices of the researchers and the wide communications with different specialist from other Polish cities and institutions all contributed to heritage research. Nevertheless, it can be said that heritage investigation would have been poorer without those who worked in Vilnius. This leads to the conclusion that individual practices for heritage research in Interwar Vilnius was very important and it created a scientific strong platform for the development of investigation methods and questions.

\section{Submitted $-20 / 12 / 2019$}




\section{Bibliography}

\section{Sources}

Borowski Jan, Wykaz prace naukowych i zawodowych inż. architekta Jana Borowskiego, in: Archive of Gdansk Politechnical university, WA_120_22.

Document of Jan Borowski, in: Archive of Gdansk Politechnical university, NLP_130_138_6.

Dokumenty prof. J. Kłosa, in: LVIA, f. 1135, ap. 12 , b. 17.

Dokumentų byla apie Vilniaus Universiteto pastatų ansambli (universiteto, Balio Sruogos, Gorkio, Tallat-Kelpšos g-vès) Atr-65a, 1921-1971, in: KPC PB, f. 3, ap. 1, b. 448.

Dzieje Murów Uniwersyteckich, in: LVIA, f. 1135 , ap. 12 , b. 71 .

Kościoł Św. Ignacego, in: LVIA, f. 1135, ap. 12, b. 69 .

KPC PB, f. 22, ap. 1, b, 16.

LCVA, f. 51, ap. 10, b. 1181.

LCVA, f. 51, ap. 10, b. 1188.

LCVA, f. 51, ap. 10, b. 1192.

LCVA, f. 52, ap. 10, b. 1186.

LNDM V-50, V-51, V-52, V-54.

LVIA, f. 1135, ap. 12, b. 96.

LVIA, f. 1135, ap. 12, b. 96.

Marian Morelowski, Raportas apie archeologinius kasinejjimus Aukštutinès ir Žemutinès pilies teritorijoje, referas, Vilnius, 194010 13, in: LLMA, f. 81, ap. 1, b. 17, 1. 2-9.

Marian Morelowski, Urbanistyka Wilna XIV $i$ $X V$, Wilno, in: Zakład Narodowy im. Ossolińskich, Dział Rękopisów, 14841/II.

Marian Morelowski, Vilnius prieš 1655 metus. Rekonstrukcinio plano 318 numeriu paaiškinimas, vertimas iš lenkų kalbos, Vilnius, 1961, rankraščio kopija, in: Vilniaus regioninis valstybès archyvas, f. 1019, ap. 11, b. 4358 .

Materiały Marian Morelowski (1884-1963). J. W. Wilno zamek dolny i górny, zamki polsko-litewskie notatki. Wypisy z literatury, rysunki, in: Archywum Polskiej Akademii Nauk, III234/112.
Remont Ratusza, in: LCVA, f. 64, ap. 8, b. 189. Stanislovas Mikulionis (1935-1992), J. Borovskio laiškas B. Krūminiui, in: LLMA, f. 455, ap. 1 , b. 315 .

Susirašinėjimo dokumentai dèl Vilniaus Bazilijonų vienuolyno „Konrado celès“ ir Vilniaus mylètojų sajungos [draugijos] $1922 \mathrm{~m}$. biudžeto projektas, 1921-1938, in: KPC PB, f. 22 , ap. 1 , s.v. 4.

Vilniaus mylètojų draugija [Towarzystwo Milośników Wilna], in: LCVA, f. 1041, ap. 1, b. 1 .

\section{References}

Bielinienė Janina, „Ką apie prof. J. Kłosą pasakoja jo knygos", in: Vilniaus architektūros mokykla XVIII-XX a., Vilniaus dailes akademijos darbai, t. 2, Vilnius: Vilniaus dailès akademijos leidykla, 1993, pp. 194-219.

Blažiūnas Juozapas, „Profesorius Janas Rutkowskis. Tarp Ars ir Sacrum", in: Acta Academiae Artium Vilnensis, Vilnius, 2015, t. 77-78: Dailès ir architektūros paveldas: tyrimai, išsaugojimo problemos ir lükesčiai, sud. Dalia Klajumienė, pp. 185-198.

Borovskis Janas, „Trakų salos pilis, kaip tvirtovè ir Didžiojo Kunigaikščio rezidencija, atliktų konservacinių darbų šviesoje“, in: Vytauto Didžiojo kultūros muziejaus metraštis, Nr. 1, sud. P. Karazija, Kaunas: Vytauto Didžiojo kultūros muziejaus leidinys, 1941, Nr. 14, pp. 199-242.

Borowski Jan, Historia architektury powszechnej, cz. 1: Architektura renesansowa I barokowa we Wtoszech, Gdańsk: Wydawnictwo Uczelniane Politechniki Gdańskiej, 1964.

Borowski Jan, Ochrona zabytków, Gdańsk: Politechnika Gdańska, Państwowe wydawnictwo naukowe, 1954.

Borowski Jan, „Dachy Gdańskie. Rekonstrukcje“, in: Ochrona Zabytków, 1949, No. 1, pp. 37-43.

Budreika Eduardas, „Mokslinio restauravimo pradininkas“, in: Vakarines naujienos, 1988 0130, p. 3. 
Ciemnołoński Janusz, Stankiewicz Jerzy, „Architekt Jan Borowski (1890-1966)“, in: Kwartalnik Architektura i Urbanistika, teoria i historia, t. 34, No. 3-4, Warszawa, 1990, pp. 243-252.

Ciemnołoński Janusz, Stankiewicz Jerzy, „Jan Borowski - architekt i konserwator“, in: Konserwator $i$ zabytek. In memoriam Jerzego Remera, Warszawa, 1991, pp. 152-162.

Ciemnołoński Janusz, „Jan Borowski - pierwszy polski wojewódzki konserwator w Gdańsku“, in: Pism PG, 1995, No. 7 (18), pp. 16-18.

Dekret Rady Regencyjnej z 31 października 1918 r. o opiece nad zabytkami sztuki i kultury, 31 października 1918, [online], 1918, [cited 2019-11-15], https://pamiecpolski. archiwa.gov.pl/dekret-rady-regencyjnej-zdnia-31-x-1918-r/.

Dettloff Paweł, „Z dziejów zjazdów konserwatorskich w Polsce. W stulecie I Zjazdu Miłośników Zabytków Ojczystych“, [online], pp. 279-287, [cited 2019-11-15], https://www. nid.pl/upload/iblock/2f5/2f5f6b5d3c79176a698adb60150f961b.pdf.

Dettloff Pawel, Odbudowa i restauracja zabztków architekturz w Polsce w latach 1918-1939: Teoria i praktyka, Kraków: Towarzystwo Autorów i Wydawców Prac Naukowych "Universitas", 2006.

Fedorovič Jolanta, „Nekilnojamojo kultūros paveldo apsauga Vilniaus krašte 1920-1939 metais: lenkiško paveldosaugos modelio raiška“, in: Lietuvos istorijos studijos, t. 29, Vilnius: Vilniaus universitetas, 2012, pp. 84-97.

Gawlicki Marcin, Zabytkowa architectura Gdanska w Latach 1945-1951. Ksatattowanie koncepcji konserwacji i odbudowy, Gdańsk: słowo/obraz terytoria, 2016.

Gizbert-Studnicki Wacław, Wilno: przewodnik ilustrowany po mieście i okolicach z planem miasta i dodatkami, Wilno: Żukowski i Borkowski, 1910.
Glemža Jonas Rimantas, Nekilnojamojo kultū ros paveldo apsauga ir tvarkymas, Vilnius: Vilniaus dailès akademijos leidykla, 2002.

Ilgiewicz Hienryka, „Vilniaus mokslo bičiuliu draugijos (1907-1939) biblioteka: komplektavimas ir fondų raida“, in: Knygotyra, 2011, Nr. 57, pp. 217-234.

Instrukcja Ministra Wyznań Religijnych i Oświecenia Publicznego z dnia 2 czerwca 1930 r. wydana w porozumieniu z Ministrem Spraw Wewnętrznych o prawach i obowiązkach Konserwatorów, jako fachowych organów wojewódzkich władz administracji ogólnej, [online], 1930, [cited2019-11-15], http://prawo.sejm.gov.pl/isap.nsf/download. xsp/WMP19301560239/O/M19300239.pdf.

Keršytė Nastazija, „Lietuvos kultūros vertybiu globos institucijos Vilniuje XX amžiaus pradžioje“, in: Vilniaus kultūrinis gyvenimas 1900-1940, Vilnius, 1998, pp. 72-81.

Kitkauskas Napaleonas, „Vilniaus pilys Mariano Moreliovskio (1884-1963) tyrimuose“, in: Vilniaus istorijos metraštis, 2007, t. 1, pp. 97-116.

Kłos Juliusz, Wilno. Przewodnik krajoznawczy Juliusza Kłosa prof. Uniwersytetu St. Batorego. Wydanie trzecie poprawione po zgonie autora, Wilno: Wyd. Wileńskiego oddziału Polskiego towarzystwa turystyczno-krajoznawczego, 1937.

Koziel Andzej, "Marian Morelowski (18841963)“, in: Rocznik Historii Sztuki, t. XXXVI, PAN WDN, 2011, p. 47-56.

Lukšionytė-Tolvaišienė Nijolè, „Menotyros mokslas tarpukario Vilniuje", in: Meno istorija ir kritika (Art History \& Criticism), t. 7: Meno istorijos riboženkliai, 2011, pp. 64-76.

Morelowski Marian, "Geneza stylu kościoła św. Anny i formy bramy Subocz w Wilnie", in: Prace i materiaty Sprawoyd. Sekcji Hist. Sztuki Tow. Przyj. Nauk w Wilnie, z. 4, Wilno, 1935, pp. 306-308.

Morelowski Marian, "Problemy wileńskiej architektury barokowej”, in: Prace $i$ materiaty Sprawoyd. Sekcji Hist. Sztuki Tow. Przyj. Nauk w Wilnie, z. 4, Wilno, 1935, pp. 245-256.
$98-2020$

Acta Academiae Artium Vilnensis 
Morelowski Marian, "Wschód i zachód a zamku Trockim na wyspie”, in: Prace $i$ materiaty Sprawoyd. Sekcji Hist. Sztuki Tow. Przyj. Nauk w Wilnie, z. 4, Wilno, 1935.

Morelowski Marian, "Zamek najeziorny Trocki a źródła jego formy zachodnie I czarnomorskie”, in: Sprawozdania z posiedzień Towarzystwa Nauk Warszawskiego, Wzdz. 2: Nauk historicznych, spolecznych $i$ filozoficynzch, Warzawa, 1947, p. 47-56.

Markevičienè Jūratė, „Kultūros paveldo saugos raiška: mokslinès, emocinès ir teisinès prielaidos", in: Vilniaus kultūrinis gyvenimas 1900-1940, Vilnius: Lietuvos literatūros ir tautosakos institutas; 1998, pp. 271-307.

Markevičienė Jūratė, „Pamiršta hipotezè, arba Vilniaus miesto sandara XIV-XV amžiuje“, in: Menotyra, sud. Gražina Marija Martinaitienè, Vilnius: Lietuvos mokslų akademijos leidykla, 2002, Nr. 3 (28), pp. 30-45.

Mikučianis Vladislovas, Norejjau dirbti Lietuvoje, Vilnius: Vilniaus dailès leidykla, 2001.

Morelowski Marian, "Rozwój urbanistyki Wrocław wiekach średnich I w dobie nowożytnej do r. 1807 [w. wyd.:]", in: Wroctaw. Rozwój urbanistyczny, Warszawa, 1956.

Morelowski Marian, "Rozwój urbanistyki Wrocławia przed kolonizacją z lat 1241-1242", in: Sprowozd. Wroct. Tow. Nauk, 1951.

Narębski Stefan, "Zarys urbanistycznego rozwoju Wilna i plan zabudowania jego z r. 1817", in: Prace i Materiały Sprawozdawcze Sekcji Historii Sztuki Towarzystwa Przyjaciót Nauk w Wilnie, Wilno, 1935, t. 2, pp. 339-344.

Obst Jan, "O Górę Zamkową”, in: Kurier Litewski, 191203 07, Nr. 44.

Paminklu squadas, Vilnius: Vyriausioji enciklopedijų redakcija, 1988, p. 173.

Pocevičius Darius, 100 istoriniu Vilniaus reliktu, Vilnius: Kitos knygos, 2016.

Poklewski Józef, “Organizacje artystyczne i intytucje opieki nad sztuką w międzywojennym Wilnie”, in: Kultura międzywojennego Wilna, Białystok: Towarzystwo Literackie im. Adama Mickiewicza, 1994, pp. 173-202.
Poklewski Józef, "Prof. Juliusz Kłos (18811933) architect - badacz - konserwator - pedagog - człowiek", in: Architektura et historia, Torun: Zakład Poligraficzno-Wydawniczy POZKAL, 1999, p. 283-313.

Povilaitytė Edita, Rutkauskienè Rima, Juozapas Kamarauskas: architekto inžinieriaus kūrybinis palikimas Lietuvos dailès muziejuje, Vilnius: Lietuvos dailès muziejus, 2016.

Povilaitytè-Leliugienė Edita, „Fotografija paveldo istorijoje: Vilniaus Aukštutinè pilis“, in: Vaizdu tekstai - tekstu vaizdai. Dailes istorijos studijos, Nr. 7, Vilnius: Lietuvos kultūros tyrimų institutas, 2016, pp. 138-142.

Reklaitis Povilas, „Morelowski Marian“, in: Lietuviu enciklopedija, 1959, t. 19, p. 269.

Remer Jerzy, Madonna warowni wileńskiej (rzecz o obrazie Matki Boskiej Ostrobramskiej), Kraków: Drukarnia Narodowa, 1927.

Remer Jerzy, Oddziat sztuki Wileńskiego urzędu Wojewódzkiego w pięcioletnim okresie dziatalności, Wilno, 1928.

Remer Jerzy, "Program inwentoryzacji zabytków sztuki w Polsce”, in: Ochrona Zabytków, No. 1-4, 1930/1931, pp. 415-416.

Remer Jerzy, “Trzydziestolecie konserwatorstwa polskiego", in: Ochrona Zabytków, R. 1/2, Warszawa, Kraków, 1948, pp. 62-64.

Rozporządzenie Prezydenta Rzeczypospolitej z dnia 6 marca 1928 r. o opiece nad zabytkami, [online], 1928, [cited 2019-11-15], http://g.ekspert.infor.pl/p/_dane/akty_pdf/ DZU/1928/29/265.pdf\#zoom=90.

Szablowski Jerzy, "Dzieje inwentaryzacji zabytków sztuki w Polsce w dwudziestą rocynicę centralnego biura inwentoryzacji zabytków sztuki”, in: Ochrona Zabytków, No. 2/2 (6), Czerwiec 1949, pp. 73-83.

Szenfeld Edward, "Dlaczego Góra Zamkowa a nie Stołowa?”, in: Kurier Litewski, 1912, No. 9 (22) lutego.

Vitkauskienė Birutė Rūta, „Iš Zygmunto Mečislavo Čaikovskio rankraščių“, in: Acta Academia Artium Vilnenesis, t. 57, Vilnius: Vilniaus dailès akademijos leidykla, 2010, pp. 123-147. 
Vitkauskienè Birutė Rūta, „Pamirštas Vilnius. Iš Vilniaus tyrinėjimų istorijos", in:

Lietuvos pilys 200\%, Vilnius: Vilniaus pilių valstybinio kultūrinio rezervato direkcija; 2008, pp. 6-23.

Zahorski Władysław, Kaplica św. Kazimierza w Wileńskiej Katedrze, Varšava:

G. A. Bernštajn, 1901.

Zahorski Władysław, Katedra Wileńska, Wilno: Nakład księgarni Józefa Zawadzkiego, 1904.

Zahorski Władysław, Kośćiót św. Anny w Wilnie, Wilno: Druk Józefa Zawadzkiego, 1905.

Zahorski Władysław, Kościót św. Michała $i$ klasztory panien Bernardynek w Wilnie, Wilno: Księg. Stow. Naucz. Polskiego, 1910.

Zahorski Władysław, Przewodnik po Wilnie: opracowany na najnowszych źródet, Wilno: nakład i własność drukarni wydawniczej Józefa Zawadskiego, [1910].

Zimna-Kawecka Karolina, "Ochrona zabytków i organizacja urzędów konserwatorskich w Polsce okresu międzywojennego (na przykładzie woj. pomorskiego) a unormowania Ustawy z dn. 23 VII 2003 r. o ochronie zabytków i opiece nad zabytkami / Monument protection and organisation of conservation offices during the interwar period in Poland (on the example of Pomeranian Voivodeship) and the norms in the Act from 23 July 2003 concerning monument protection and care for monuments", in: Wiadomości Koserwatorskie, No. 27/2010, pp. 123-143.

\section{Abbreviations}

KPC PB (Kultūros paveldo centro paveldosaugos biblioteka) - Heritage Protection Library of the Cultural Heritage Centre

LCVA (Lietuvos centrinis valstybės archyvas) Lithuanian Central State Archives

LLMA (Lietuvos literatūros ir meno archyvas) - Lithuanian Archives of Literature and Art
LNDM (Lietuvos nacionalinis dailès muziejus) - Lithuanian National Museum of Art

LNM (Lietuvos nacionalinis muziejus) National Museum of Lithuania

LVIA (Lietuvos valstybės istorijos archyvas) Lithuanian State Historical Archives

VRVA (Vilniaus regioninis valstybės archyvas) - Vilnius Regional State Archives
98 2020

Acta Academiae Artium Vilnensis 
Santrauka

\section{Tarpukario Vilniaus architektūrinio palikimo tyrimai: problemos ir metodai}

Edita Povilaitytè-Leliugienè

Reikšminiai žodžiai: architektūrinio paveldo tyrimai, paveldosauga, įsiterpiantys ir neįsiterpiantys tyrimai, konservavimas, restauravimas, inventorius, tarpukario Vilnius.

Straipsnyje pristatomos tarpukario Vilniaus architektūrinio paveldo problemos ir tyrimų metodai. Atsižvelgiant ị institucinị reglamentavimą ir šalies įstatymines rekomendacijas, architektūrinio paveldo tyrimai turèjo būti atliekami prieš visus išsaugojimo darbus (konservavimą, restauravimą ir adaptavimą), nors tyrimų kiekis bei kokybė ir skyrèsi nuo ịprastinių bei nuo atliktos inventorizacijos (tiriamųjų piešinių) ir neįsiterpiančių tyrimų metodų analizès. Lyginamoji institucinio poveikio tyrimams ir individualioms tyrèjų praktikoms analizè atskleidè kur kas platesnius tarpukario Vilniaus architektūrinio paveldo tyrimų, klausimų ir metodų kontekstus. 